\title{
Arachidonic Acid Metabolites in Cardiovascular and Metabolic Diseases
}

\author{
Thomas Sonnweber@, Alex Pizzini, Manfred Nairz, Günter Weiss@ and Ivan Tancevski * \\ Department of Internal Medicine II, Medical University Innsbruck, Innsbruck 6020, Austria; \\ Thomas.Sonnweber@i-med.ac.at (T.S.); Alex.Pizzini@i-med.ac.at (A.P.); Manfred.Nairz@i-med.ac.at (M.N.); \\ guenter.weiss@i-med.ac.at (G.W.) \\ * Correspondence: Ivan.Tancevski@i-med.ac.at; Tel.: +43-512-504-81602
}

Received: 30 September 2018; Accepted: 21 October 2018; Published: 23 October 2018

\begin{abstract}
Lipid and immune pathways are crucial in the pathophysiology of metabolic and cardiovascular disease. Arachidonic acid (AA) and its derivatives link nutrient metabolism to immunity and inflammation, thus holding a key role in the emergence and progression of frequent diseases such as obesity, diabetes, non-alcoholic fatty liver disease, and cardiovascular disease. We herein present a synopsis of AA metabolism in human health, tissue homeostasis, and immunity, and explore the role of the AA metabolome in diverse pathophysiological conditions and diseases.
\end{abstract}

Keywords: arachidonic acid; eicosanoids; metabolic disease; obesity; nonalcoholic fatty liver disease; diabetes; atherosclerosis; cardiovascular disease; cholesterol

\section{Introduction}

An overlapping incidence of obesity and various metabolic, as well as cardiovascular diseases, has been recognized for a long time [1,2]. Despite improvements in the treatment and the reduction of mortality from cardiovascular diseases within the last years, the tremendous increase in the prevalence of obesity and its associated comorbidities threatens to subvert these advances [3]. By 2010 the prevalence of obesity, as defined by a body mass index (BMI) above 30, has spiked to 36 percent of female and male adults in the United States [3], and the World Health Organization (WHO) estimated that, in 2016, over 1.9 billion adults and 340 million children and adolescents were overweight or obese worldwide [4]. These alarming numbers indicate that obesity nearly tripled within the last 40 years, with increasing numbers of obesity-associated diseases that are considered a major challenge of modern medicine. Over- or malnutrition, especially high fat and carbohydrate intake, lack of exercise and sedentary lifestyles are the main causes for weight gain and obesity. The latter is associated with a plethora of metabolic and cardiovascular diseases, including diabetes mellitus (DM), non-alcoholic fatty liver disease (NAFLD), non-alcoholic steatohepatitis (NASH), atherosclerosis, myocardial infarction and stroke, which have a major impact on mortality worldwide [5-7].

Early studies defined obesity and its related morbidities as simple lipid-storage diseases [8-10]. Still, the understanding of the pathophysiology involved in obesity-associated diseases has vastly increased within the last decades, pointing towards shared features of altered nutrient metabolism, and chronic inflammation to be key components in disease development [11-15]. In this context, arachidonic acid (AA) metabolism provides an interesting link between lipid metabolism and immunity and was implicated in the emergence and course of cardiovascular and metabolic diseases [16]. We herein review the current knowledge of the regulation of AA metabolism and its impact on human health and disease focusing on recent advances in the understanding of AA metabolism in obesity, DM, NAFLD/NASH, atherosclerosis, and cardiovascular disease. 


\section{AA Metabolism}

In the context of nutrition and medicine, the term AA typically refers to all-cis-5,8,11, 14-eicosatetraenoic acid, an omega-6 polyunsaturated fatty acid (PUFA), which consists of twenty carbon chains and four cis double bonds. PUFAs are abundantly present in phospholipids of human cell membranes, and in lipid droplets (LDs) in immune cells [17-20]. According to the twenty carbon units in length, AA and its derivatives, as well as various omega-3 PUFAs, are also termed eicosanoids. The highest concentrations of AA are found in the brain, muscle, liver, spleen, and retina, whereas concentrations of free AA in the circulation are typically very low due to albumin binding and trafficking to cells $[17,21]$.

Various foods serve as an exogenous source of AA for humans. Lean meat and meat fats, eggs, salmon and tuna contain high concentrations of AA [22-24], and AA is also derived from linoleic acid, an essential fatty acid, which is mainly found in vegetable oils and walnuts [25]. Endogenous AA generation mainly occurs via the release of AA from cell membrane phospholipids. This process is catalyzed by enzymes of the phospholipase A2 (PLA2) superfamily and is induced by various cellular activation signals, including inflammation or infection driven tumor necrosis factor receptor (TNFR) and toll-like receptor 4 (TLR4) stimulation [26,27]. Among the PLA2 enzymes superfamily, three members contribute to eicosanoid production and are involved in distinct functions of eicosanoid metabolism. The cytosolic $\mathrm{Ca}^{2+}$ dependent PLA2 (cPLA2) alpha mainly drives free fatty acids (FFAs) production and generation of AA, which is involved in cellular signaling. The cytosolic $\mathrm{Ca}^{2+}$ independent PLA2 (iPLA2) alpha contributes to cellular homeostasis via the synthesis of specialized pro-resolving mediators (SPMs) and reacylation of free AA, and the secretory PLA2 (sPLA2) controls free AA release and induces the local inflammatory response in a paracrine manner $[27,28]$. In addition to PLA2, two other phospholipase families, namely phospholipase C (PLC) and phospholipase D (PLD), generate AA via intermediate products such as diacylglycerol (DAG) $[29,30]$. Finally, endocannabinoids serve as an endogenous source for AA, as demonstrated by the generation of AA from anandamide [31].

Four enzymatic pathways process free AA, resulting in the generation of a plethora of AA derivatives with multitudinous functions (Figure 1). First, cyclooxygenase 1 (COX1) and 2 (COX2), also known as Prostaglandin G/H synthases, foster the production of thromboxane A2 (TXA2), prostacyclin (PGI2) and several prostaglandins (PGs) [32,33]. COX1 is constitutively expressed and found in all tissues, which are prone to lipopolysaccharide (LPS) induced inflammation. TXA2 and prostaglandins (PGs), such as prostaglandin D2 (PGD2), are metabolites of the COX1 pathway, and alter the vessel tone, mediate platelet aggregation and are implicated in immune surveillance [34-39]. COX2 is found in macrophages and endothelial cells, demonstrates high expression levels in the kidney and brain, and is induced by bacterial endotoxins, growth factors, hormones, and several cytokines [40]. Its major metabolites prostaglandin E2 (PGE2), PGI2, PGD2 and prostaglandin F2alpha (PGF2 $\alpha$ ) adapt host immune response, vessel tone regulation, thrombus formation, pain reception, and female fertility, and are involved in neurodegeneration and cancer [41-47]. Additionally, COX3, a splice variant of COX1, facilitates prostaglandin synthesis in the human brain and heart [48].

Second, four lipoxygenases (LOX), namely 5-LOX, 8-LOX, 12-LOX and 15-LOX, process AA. 5-LOX produces 5-hydroperoxyicosatetraenoic acid (5-HPETE), 5-hydroxyicosatetraenoic acid (5-HETE), and 5-oxo-eicosatetraenoic acid (5-oxo-ETE), as well as various leukotrienes (LTs) [49]. These metabolites affect neutrophil recruitment and diapedesis, epithelial barrier function, vascular permeability and bronchoconstriction [50-54]. 8-LOX and 15-LOX lipoxygenases convert free AA to 8and 15-hydroperoxyicosatetraenoic acid (8-HPETE and 15-HPETE) and foster the production of 15-HPETE derivatives, such as 15-hydroxyicosatetraenoic acid (15-HETE), lipoxins and eoxins [55-58]. 12-LOX metabolize AA to 12-hydroperoxyeicosatetraenoic acid (12-HPETE), which itself serves as a precursor for 12-hydroxyeicosatetraenoic acid (12-HETE) and to hepoxilins [58]. AA derivatives from the 8-, 15-, and 12-LOX pathways are involved in the establishment of hyperalgesia and induce the expression of fatty acid translocase [59,60]. Lipoxins exert mainly anti-inflammatory properties. Interestingly, their synthesis is induced by the COX inhibitor aspirin, an antithrombotic agent widely used in the treatment and for secondary prevention of cardiovascular diseases [61,62]. 
Third, the cytochrome P450 (CYP450) pathway, which is mainly restricted to the liver and is well known for its function in detoxification, includes epoxygenase and $\omega$-hydroxylase, which facilitate the production of epoxy-eicosatrienoic acids (EETs) and hydroxy-eicosatetraenoic acids (HETEs), respectively. These AA derivatives regulate vessel constriction and dilation, hamper hyperalgesia, and inhibit COX2 expression [63-66].

Fourth, anandamide, an endocannabinoid, is generated from AA via the fatty acid amide hydrolase (FAAH) in a reversible reaction [67], whereas the processing of anandamide to AA and ethanolamine takes place when tissue damage is associated with high levels of free AA [68]. In this situation, anandamide supports tissue regeneration, and cellular proliferation via interaction with cannabinoid type 1 (CB1) receptors [69].

Finally, free AA is also processed by non-enzymatic reactions. The four double bonds of AA are readily oxygenated to form bioactive molecules. Thus, oxidative stress and/or exposure of AA to reactive oxygen species (ROS) and reactive nitrogen species (RNS) result in oxidation of AA and generate isoprostanes and nitroeicosatetraenoic acids [70-72]. These eicosanoids were reported to inhibit COX1, whereas isoprostanes have been linked to platelet aggregation, vasoconstriction, smooth muscle cell proliferation, and cardiomyocyte hypertrophy [72-74]. To conclude, AA and its derivatives can enter numerous metabolic pathways that interconnect lipid metabolism with immunity. A synopsis of key enzymes, metabolites, and biological functions of the AA metabolism is depicted in Figure 1.
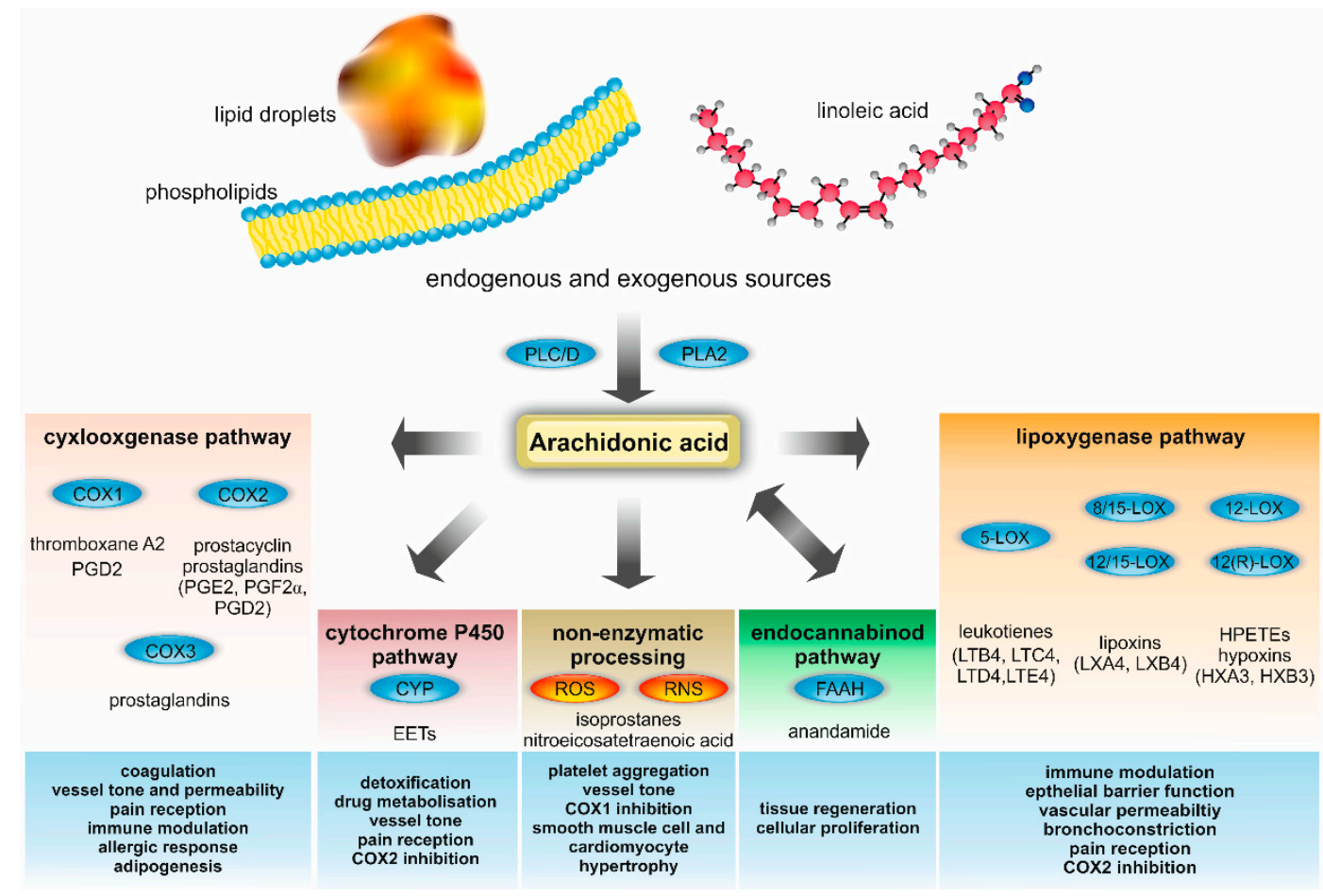

Figure 1. Metabolites and enzymes involved in AA metabolism and their biological functions in metabolic and cardiovascular diseases. Endogenous AA is mainly derived from cell membrane phospholipids, which are processed by phospholipase A2 (PLA2), phospholipase C (PLC), and phospholipase D (PLD). Free AA serves as a precursor for a plethora of metabolites, including prostaglandins (PGs), prostacyclin, thromboxane, HPETE, leukotrienes, lipoxins, hypoxins, anandamide, and epoxyeicosatrienoic acids (EETs). In addition to this enzymatic processing of AA, there is also a non-enzymatic metabolization. The latter is important for the production of isoprostanes and nitroeicosatetraenoic acid. Many AA metabolites are highly bioactive and involved in various crucial vital processes. Relevant biological functions in metabolic and cardiovascular diseases are summarized in the blue boxes at the bottom. Additional abbreviations used: COX, cyclooxygenase; CYP, cytochrome; ROS: Reactive oxygen species; RNS: Reactive nitrogen species; FAAH, fatty acid amide hydrolase; HX, hypoxin; LOX, lipoxygenase; LT, leukotriene; and LX, lipoxin. 


\section{AA Metabolism in Human Health}

In line with the plethora of AA derivatives and their functions, AA metabolism is important for human health and tissue homeostasis. AA itself confers cell membranes with flexibility and fluidity, serves as a lipid second messenger in cellular signaling, acts as an inflammatory intermediate and induces vasodilatation $[27,75]$. AA alters ion channel fluxes and voltage-gated proton pumps, including the modulation of $\mathrm{Na}^{+}$channels in the heart, which are major contributors to cardiac excitability [76]. The modulation of proton pumps and $\mathrm{pH}$ is also essential for the NADPH oxidase mediated production of ROS by phagocytes, thus free AA induces oxidative stress [77,78]. As previously mentioned, oxidative stress per se has dramatic consequences on AA metabolism, as it alters AA release by PLA2, fosters auto-oxidation of AA and induces COX2 over-expression [79]. The induction of ROS by free $\mathrm{AA}$ is a major factor for its described roles in immune surveillance, apoptosis regulation and its possible tumoricidal activity [80,81], and is of special interest in cardiovascular and metabolic diseases, because oxidative stress is a relevant factor in the pathogenesis of DM, hypertension, hepatic steatosis, atherosclerosis, and heart disease [82]. In this context, oxidative stress induces insulin resistance in adipocytes and muscle cells via interaction with PI3-kinase and Akt signaling, decreases insulin secretion by $\beta$ cells, alters cellular glucose uptake and lipogenesis [75]. Accordingly, antioxidants, such as NADPH oxidase inhibitors, are a promising treatment option for cardiovascular and metabolic diseases.

In humans, AA plasma levels typically range from $0.1 \mu \mathrm{M}$ to $50 \mu \mathrm{M}$, whereas under pathophysiological conditions, AA plasma concentrations up to $500 \mu \mathrm{M}$ can be found [83,84]. Interestingly, $50 \mu \mathrm{M}$ to $100 \mu \mathrm{M}$ of free AA are cytotoxic in vitro, thus it is likely that plasma AA concentrations found in the human body exert cytotoxic and apoptosis regulatory functions. Accordingly, AA is essential in embryogenesis and infant development, but may also be a driving factor in cardiovascular, metabolic and inflammatory diseases [85]. In line with this, several studies have found an inverse relationship of plasma AA concentrations and the risk of coronary heart disease [86-88]. Thus, it is important to elucidate any potential influence of AA on various aspects in human health.

AA metabolites are implicated in immune surveillance, the establishment of allergy, the initiation and resolution of an inflammatory response, platelet aggregation and the coagulation cascade, glucose metabolism, neuronal signaling, female fertility, and the adaptation of mood and appetite [17]. Interestingly, available enzyme cassettes to process AA and G-protein coupled receptors are different for each cell and tissue type, ensuring a cell/tissue-specific regulation and function of AA metabolism [89]. The functional state of cells (e.g., activated vs. non-activated macrophages) and tissue environment impact on the synthesis of AA derivatives, and the necessity for cell-cell interactions to produce specific eicosanoids, also termed transcellular biosynthesis, adds further complexity to AA metabolism [90,91]. Targeted lipidomic strategies using mass spectrometry-based technology platforms revealed that the compound effect of local lipid metabolites, and their time-dependent generation, determine the biological function of the AA metabolome, rather than the specific concentration of a single eicosanoid at a given site and time point [92]. This was also demonstrated by the partial inhibition of the immunomodulatory effects of FFAs by omega-3 PUFAs, such as eicosapentaenoic acid (EPA) and docosahexaenoic acid (DHA), which display anti-inflammatory properties and are precursors for pro-resolving SPMs [93,94]. SPMs, including resolvin D1, enhance phagosome formation in macrophages and are capable of reverssing the phagocytic defect of macrophages derived from diabetic mice. They may thereby counter-balance the effects of pro-inflammatory AA metabolites [95].

A detailed description of all functions of eicosanoids would go far beyond the scope of this review, but the interested reader may be referred to some excellent recent studies and reviews covering specific aspects of eicosanoid metabolism in more detail [13,16,33,64,92,96-102]. As far as the pathophysiology of metabolic and cardiovascular diseases is concerned, immune regulatory, pro-inflammatory, and inflammation resolving functions of the AA metabolism are of major importance $[16,96,103])$. Immune surveillance depends on the establishment of inflammation, which normally occurs as regulated and self-limited process. However, inflammatory stimuli may persist and mechanisms of resolution 
may fail, resulting in excessive or persistent inflammation in various pathophysiological conditions [99]. An acute inflammatory response is characterized by an initiation phase and a resolution phase and is clinically featured by the symptomatic complex of heat, swelling, pain, and eventually loss of function [96]. Both the initiation and resolution of inflammation are mainly controlled by local chemical autacoids, which present a potpourri of proteins, peptides and lipid-derived mediators (especially AA-derived leukotrienes and prostaglandins) [96]. These messengers regulate chemotaxis and function of leukocytes and alter the pro-resolving activity of tissue phagocytes. Whereas an acute inflammatory response is essential for host surveillance, dysregulation of pro-inflammatory and anti-inflammatory signaling cascades, as well as the lack of pro-resolving mediators, result in persistent tissue inflammation. The latter promotes tissue dysfunction, damage, and fibrosis, and has been implicated in various diseases [97]. Of note, ample evidence links chronic inflammation, even at low-grade levels, to the emergence and progression of metabolic and cardiovascular diseases [12,52,57,103-107], and various AA metabolites, especially prostaglandins, leukotrienes, and thromboxanes are highly bioactive and contribute to the establishment of unresolved chronic inflammation [16,97].

It has long been recognized that nutrition affects the functionality of immune and non-immune cells, and metabolic dysregulation results in a pro-inflammatory signaling in polymorphonuclear neutrophils (PMNs), macrophages, endothelial cells, and adipocytes [13,108,109]. Various diseases are linked to metabolic dyshomeostasis, including obesity, diabetes, NAFLD/NASH, and atherosclerosis $[5,15,99,110,111]$. The interaction of inflammation and metabolism is a double-edged sword: whereas metabolic stress induces inflammation, inflammation per se disrupts metabolic homeostasis. Thus, chronic metabolic or inflammatory diseases typically present a vicious feedforward cycle of dysregulated metabolism and inflammatory response.

Various trials have investigated the effects of alimentary PUFA supplementation and both omega-3 and omega-6 PUFA rich diets have been proposed to reduce the risk of cardiovascular and metabolic diseases. Consequently, dietary guidelines have included information on the appropriate consumption of omega-3 and omega-6 PUFAs, which aim to prevent deficiency of essential PUFAs and take possible beneficial and detrimental effects of alimentary PUFA supplementation into account. For instance, a FAO expert consultation report recommended a consumption of two-to-three percent of energy (\%E) linoleic acid and 2.5 to $9 \% \mathrm{E}$ omega-6 PUFAs per day [112]. Still, these recommendations are controversial, because they are challenged by contrasting results of various trials and meta-analyses [113-118].

\section{Alterations of Immunity and Wound Healing in Obesity and Metabolic Disease}

Malnutrition, chronic over-feeding, and obesity are associated with the accumulation of triglycerides (TGs) in adipose tissue and ectopic TG deposition in various other tissues, including the skeletal muscle and the liver [15]. Lipolysis of TGs produces FFAs, which are highly toxic and induce pro-inflammatory signaling cascades in immune and non-immune cells via activation of pattern recognition receptors such as TLR2 and TLR4 [119]. Despite the accumulation of FFAs, obesity-associated exceedance of the body lipid storage and metabolization capacities also results in an overload with fatty acid intermediates, such as ceramides and DAG [120,121]. The latter are known precursors of AA thus foster the production of pro-inflammatory AA metabolites, including PGE2, leukotrienes, and HETEs, and an accumulation of DAG is implicated in insulin resistance [122-124]. The emergence of FFAs and induced eicosanoid pathways impair leukocyte function, contribute to PMN survival and persistence at inflamed sites, and decrease phagocytosis and efferocytosis, the local phagocytic clearance mechanism of apoptotic cells by tissue macrophages [5,125]. In contrast, anti-inflammatory AA metabolites, such as lipoxin A4 (LXA4), decrease obesity-induced adipose inflammation, attenuate pro-inflammatory M1 macrophages, and foster anti-inflammatory M2 macrophages [126].

In addition, nutrient excess is associated with chronic inflammation, and obese and diabetic patients are prone to infections [127]. This observation was mechanistically linked to an 
impairment of leukocyte function, as lipid exposure hampers macrophage phagocytosis and efferocytosis [128-131]. Interestingly, autocrine actions of COX2-derived prostaglandins, such as PGE2 and PGD2, are implicated in this process, linking AA metabolism to macrophage function and immune surveillance in obese and diabetic patients [125,132]. As previously noticed, AA and its metabolites affect cell membrane fluidity, which is also important for phagocytosis and containment of microbes and may thus represent another link between AA metabolism and macrophage function.

Prostaglandins are among the most potent pro-inflammatory mediators, as reflected by their contribution to the development of toxic shock syndrome $[133,134]$. Following LPS stimulation, the COX2 pathway elicits high levels of the severe fever mediator PGE2, and 5-LOX enzymes induce LT-mediated upregulation of adhesion molecules and accumulation of inflammatory leukocytes in affected tissues. Murine knockout models for COX2 and 5-LOX demonstrated that these eicosanoid pathways are essential in LPS-triggered fever and endotoxic shock $[133,134]$. On the contrary, murine infection models, introducing either intraperitoneal E. coli, intraperitoneal Staphylococcus aureus or Staphylococcus aureus skin infection, reported a beneficial effect of a co-treatment with antibiotics and eicosanoid-derived SPMs [93].

The susceptibility to infections and the immunomodulatory effects of lipid mediators are also implicated in impaired wound healing, another feature typical of obese and diabetic patients. Disturbed wound healing has been related to insufficient perfusion, neuropathy, micro- and macrovascular disturbances, and wound infections [135]. Leucocyte dysfunction and accumulation, as well as accumulation of apoptotic and necrotic cells along with defects in autophagy at sites of delayed wound healing, are pivotal contributors to this process and are triggered by the metabolic dysregulation in these individuals $[130,136]$. In this context, a study demonstrated that leptin receptor-deficient $d b / d b$ mice, which present a genetic model for obesity and diabetes, display an impaired wound healing, which was associated with a blunted macrophage function and efferocytosis, and could be reversed by treatment with pro-resolving lipid metabolites [95]. Several AA metabolites, including PGE2, PGI2, leukotriene B4 (LTB4), leukotriene D4 (LTD4), and LXA4 are involved in wound healing [137]. Excessive LTB4 production has recently been linked to an increased risk for skin infection and impaired wound healing in diabetic mice, and was resolved following the blockade of LTB4 signaling [138]. In contrast, a beneficial effect of LXA4 containing microparticles in the topical treatment of skin lesions was described in a rat model [139] and PGE2 is involved in immune surveillance of the skin and supports dendritic and Thelper $\left(\mathrm{T}_{\mathrm{H}}\right)-17$ cell-mediated defense against staphylococcal skin infection [140].

\section{AA Metabolism in the Pathogenesis of Diabetes Mellitus}

Diabetes mellitus type 1 (DM1) and DM2 are by definition associated with recurrent hyperglycemia due to insufficient insulin production and insulin resistance, respectively. Hyperglycemia induces the production of pro-inflammatory mediators by PMNs, gives rise to oxygen radical formation, hampers PMN chemotaxis, and supports the adhesion of PMNs to the vasculature in diabetic mice [141]. Additionally, FFAs activate the NLRP3-ASC (for NACHT, LRR and pyrin domains-containing protein 3/apoptosis-associated Speck-like protein containing a CARD) inflammasome, and a disruption of the associated Nod-like receptors (NLRs) protects against insulin resistance and hyperglycemia in obesity [142]. Glucose and lipid metabolism share various metabolic pathways. Consequently, disturbances in glucose and lipid metabolism are tightly related, and over-nutrition and/or obesity ensue both, dysregulated lipid metabolism and hyperglycemia. Insulin sensitivity is determined by the interplay of multiple organ systems, namely pancreas, liver, skeletal muscle, adipose tissue, and the nervous system, whereas insulin production mainly depends on pancreatic $\beta$-cell function. High levels of FFA are accompanied by defective insulin signaling and $\beta$-cell dysfunction [119]. This effect of FFAs is mediated, at least in part, by TLR4/MyD88 (for Myeloid Differentiation primary response 88) signaling, and the recruitment of M1 macrophages to pancreatic islets [143]. Accordingly, TLR4-null mice are resistant to FFA induced adipose inflammation and 
insulin resistance [144]. Macrophages derived from diabetic mice have a pro-inflammatory phenotype and express high levels of acyl-CoA synthetase 1 (ACSL1). ACSL1 is implicated in the generation of pro-inflammatory prostaglandins, such as PGE2, thus fostering pro-inflammatory functions of macrophages [145]. Consequently, disruption of ACSL1 in myeloid cells significantly reduces the inflammatory signaling in diabetic macrophages and hampers the progression of atherosclerotic lesion in diabetic mice [145]. Similar to the previously described observations following FFA challenge, hyperglycemia in non-obese mice interferes with phagocyte function of macrophages, ensued by defects in bacterial clearance and efferocytosis [128,146]. Interestingly, AA metabolism is involved in both, FFA and hyperglycemia-mediated effects on macrophage function. AA is a strong inducer of insulin secretion, whereas its metabolites demonstrate a divergent contribution to insulin resistance, depending on the involved cells and tissues [147]. PGE2 hampers insulin secretion in pancreatic islets, and enhances pancreatic $\beta$-cell dysfunction and destruction, whereas PGI2 improves insulin sensitivity of pancreatic cells. Contrarily, PGE2 fosters adipogenesis in white fat tissue and induces glycogenolysis and gluconeogenesis, thus alleviating insulin resistance of adipocytes [147]. Recently, PGF2 $\alpha$, which is synthesized at higher levels in diabetic mice, was linked to hepatic gluconeogenesis, a major driver of fasting hyperglycemia in DM2 [148]. Additionally, the 12/15-LOX enzymes are linked to DM. 12/15-LOX enzymes induce the production of various HPETEs, which interact with peroxisome proliferator-activated receptor (PPAR) $\alpha$ and PPAR $\beta$, and are implicated in cytokine-mediated damage of pancreatic $\beta$-cells. 12/15-LOX knockout mice demonstrate a partial resistance to diabetes development [147,149-151]. Similarly, LTs, produced by 5-LOX and 12-LOX-derived HETEs, demonstrate inhibitory effects upon pancreatic insulin secretion, and genetic disruption or pharmacological inhibition of these LOXs protects against pancreatic islet cell destruction in diabetic mice [152]. In this context, LTB4 has been found to be essential for the recruitment and activation of adipose tissue B2 lymphocytes, which contribute to the establishment of insulin resistance following high-fat diet [153]. CYP450-derived EETs and 20-HETE induce insulin secretion and protect pancreatic islet cells from apoptosis [154,155]. Diabetes and obesity are associated with an enhanced expression of the soluble epoxide hydratase (sEH), a key enzyme in the degradation of EETs, and genetic deletion of sEH ensues an improved insulin sensitivity and an anti-apoptotic effect on pancreas islet cells in a murine diabetes model [156]. Accordingly, the therapeutic potential of sEH inhibitors was tested in several clinical trials. Whereas results of some trials are still pending (e.g., NCT03486223), a Phase II trial introducing a thrice-daily application of an orally administered sEH inhibitor in patients with mild to moderate arterial hypertension and pre-diabetes, failed to demonstrate an improvement of insulin sensitivity (NCT00847899). Finally, AA also facilitates the production of anti-inflammatory lipoxins. The latter were reported to improve insulin sensitivity and may prevent the development of DM [157]. For instance, LXA4 inhibits IL-6, TNF- $\alpha$, and ROS production thus hampers obesity-associated inflammation and has an anti-diabetic effect [126,158-160]. Notably, a pooled analysis of twenty prospective trials investigating biomarkers for the eicosanoid pathway demonstrated a lower incidence of DM2 in individuals with higher proportions of linoleic acid biomarkers, suggesting that SPMs other than lipoxins harbor anti-diabetic features [161]. In summary, AA derivatives play diverse and partly contrasting roles in the pathogenesis of DM. Therefore, research in AA metabolism and its enzymatic pathways may identify novel targets for the treatment of DM and its associated co-morbidities.

\section{AA Metabolites in Hepatic Steatosis and Steatohepatitis}

The most prominent hepatic disease associated with mal- and/or excessive nutrition associated metabolic dysfunction is non-alcoholic fatty liver disease (NAFLD), which may progress to non-alcoholic steatohepatitis (NASH), hepatic fibrosis, and liver cirrhosis. NAFLD is the most frequent cause of chronic liver disease, with a reported worldwide prevalence of $25 \%$ [162], and is a main driver of increasing rates of hepatocellular carcinoma (HCC) in Western civilizations [163-165]. The prevalence of NAFLD closely correlates with an elevation of the BMI, dyslipidemia, DM, 
and insulin resistance [166]. An accumulation of intracellular lipids and the formation of lipid droplets (LDs) in the cytoplasm of hepatocytes without inflammation is the typical histological finding in isolated steatosis, whereas pathologic inflammation leading to cell necrosis is present in NASH. LDs were described to be a source of excessive production of pro-inflammatory eicosanoids, suggesting an early involvement of AA metabolites in NAFLD [167]. Progression from non-inflammatory steatosis to NASH is conceived as a sequential process, still pathophysiological features of isolated steatosis and NASH are quite distinctive [168]. Similar to other metabolic diseases, dysfunction of local tissue macrophages, namely Kupffer cells, and the activation of a lipid autocoid-cytokine-chemokine cascade ensued by the activation of stellate cells, are considered crucial factors in the development of the more progressive liver disease. Currently, a multiple hit theory is the most accepted concept to explain the pathogenesis of NAFLD and NASH [169]. In addition to environmental factors, such as fructose-rich nutrition and lack of exercise, genetic variants associated with alterations in lipid metabolism, hyperinsulinemia, insulin resistance, and immunometabolic effects of altered adipokine production (e.g., alterations in leptin, adiponectin, and resistin expression), changes of the gut microbiome, increased emergence of FFAs, and inflammatory lipid-mediators were found to contribute to disease progression [169-172].

The involvement of eicosanoids in NAFLD and NASH has been established by several lines of evidence. First, genetic disruption of PLA2, the rate-limiting key enzyme in AA production, alleviates high-fat diet-induced hepatic steatosis and results in reduced PGE2 levels in mice.

Second, 5-LOX-derived LTs are implicated in the pathogenesis of NAFLD, as both mice and humans suffering from NAFLD demonstrate a significantly increased activity of the 5-LOX pathway, and the enhanced expression of 5-LOX derivatives correlates with the severity of the hepatic disease $[173,174]$. A disruption of the 5-LOX pathway in hyperlipidemic apolipoprotein E (apoE) deficient mice reduces hepatic inflammation and tumor necrosis factor alpha (TNF $\alpha$ ) dependent hepatic injury, and deficiency in leukotriene B4 receptor 1 (LTB4R, also known as BLT1), alleviates systemic insulin resistance in diet-induced obesity $[175,176]$. Accordingly, treatment with 5-LOX inhibitors mitigates hepatocellular steatosis and damage, and improves lipid transport via induction of very low-density lipoprotein (VLDL) secretion in leptin-deficient $o b / o b$ mice. Similarly, genetic disruption of the 12/15-LOX pathway is protective against the development of NAFLD in hyperlipidemic mice [177]. To conclude, pro-inflammatory LOX pathways are considered major drivers of the progression of NAFLD to NASH, and the resolution of inflammation depends on the interaction of Kupffer cells and hepatocytes, to produce anti-inflammatory/pro-resolving lipoxins, such as LXA4 and lipoxin B4 (LXB4), via transcellular synthesis.

Third, Kupffer cells produce pro-inflammatory cytokines such as interleukin- 6 and TNF $\alpha$, as well as pro-inflammatory lipid mediators like the COX2-derived PGE2, which interact with hepatocyte lipid handling [178]. Interestingly, PGE2 promotes lipogenesis and inhibits tissue growth factor beta 1 (TGF 31 )-mediated collagen production by activated stellate cells, suggesting an anti-fibrotic function of PGE2 [179]. Additionally, the COX pathway is involved in the pathogenesis of NAFLD through its effects on PPAR $\gamma$, which is implicated in insulin resistance and hepatic steatosis [180].

Fourth, enzymes of the CYP450 family are involved in both the production of anti-inflammatory EETs and HETEs [181], and the generation of ROS, which are considered to be a driving factor in steatohepatitis [182]. A role of CYP450 enzymes in NAFLD pathogenesis is also delineated by genomic analysis, demonstrating that several CYP gene variants determine susceptibility to the establishment of NAFLD/NASH [183]. Finally, serum levels of endocannabinoids are increased in obese and non-obese patients with NAFLD and may reflect an additional, thus far more poorly defined, role of eicosanoids in the pathogenesis of NAFLD [184].

In contrast, eicosanoids derived from omega-3 fatty acids exert a protective function against obesity-induced insulin resistance and NAFLD, as demonstrated by nutritional supplementation of omega-3 fatty acids in leptin receptor-deficient $d b / d b$ mice. Moreover, in fat- 1 mice, which display an increased omega- 6 to omega- 3 fatty acid ratio, transgenic expression of an omega- 3 fatty acid 
desaturase restored omega-3 fatty acid levels, thereby critically improving steatohepatitis $[185,186]$. In line with this, omega-3 fatty acid-derived SPMs, such as resolvins, are protective against the development of NAFLD [96].

To date, no established pharmacological treatment is available for NAFLD and NASH. Still, changes in food intake, the use of anti-oxidant agents, anti-inflammatory lipid mediators, and disruption of lipoxygenase pathways offer promising treatment targets in NAFLD [170,174-176,187,188].

\section{AA Metabolome in Atherosclerosis and Cardiovascular Disease}

Atherosclerosis is characterized by a remodeling of arteries, leading to sub-endothelial accumulation of lipids and development of plaques, which narrow the arterial lumen and limit blood flow. Its cardiovascular complications, including heart failure and myocardial infarction, peripheral vascular disease, stroke, retinopathy, and kidney dysfunction contribute significantly to morbidity and mortality worldwide $[2,11]$. The pathophysiology of atherosclerosis resembles various features of metabolic and immunological changes found in obesity $[189,190]$. For instance, a significant role of lipids and inflammation is a striking feature of both diseases $[1,8,11,13]$. Hypercholesterolemia and lipoprotein imbalances, such as increases in low-density lipoprotein cholesterol (LDL-C) and enhanced production of oxidized LDL-C contribute to vascular wall inflammation via interaction with pattern recognition receptors of accumulating macrophages, as demonstrated for TLR4 and TLR2 receptors, and activation of these pathways are linked to progressive atherogenesis and increased cardiovascular risk $[144,191,192]$. Despite the historical view of atherosclerosis as a lipid storage disease, the involvement of pro-inflammatory monocytes and local tissue macrophages as major protagonists in the generation and progression of atherosclerotic lesions has expanded our understanding of its pathophysiology, and also provided mechanistic insight into the role of cholesterol in cardiovascular diseases [193-196]. Following chronic mal-/over-nutrition, macrophages in vessel walls engulf excessive amounts of oxidized LDL-C and transform into foam cells. These cells are known to have a pro-inflammatory phenotype and hampered phagocyte function. They critically contribute to the accumulation of cell debris and thrombotic material in atherosclerotic lesions. The release of pro-inflammatory cytokines by foam cells further increases the synthesis of atherogenic oxidized LDL-C, resulting in a vicious feed-forward loop of chronic local inflammation. Similarly, monocytes demonstrate a predominant pro-inflammatory phenotype in atherosclerosis. According to their heterogeneity in function and phenotype, different types of circulating monocytes, namely Ly6 $\mathrm{Chi}$ and Ly6 $\mathrm{C}^{\text {low }}$ monocytes, have been identified in mice. Ly6 $\mathrm{C}^{\text {hi }}$ monocytes have mainly pro-inflammatory functions, traffic to the atherosclerotic lesion and are considerably increased in hypercholesterolemic mice [193]. In contrast, Ly6C ${ }^{\text {low }}$ monocytes, which implicate in tissue homeostasis, are less prone to enter atherosclerotic plaques [197]. In humans, three subsets of monocyte populations have been characterized, namely $\mathrm{CD} 14^{++} \mathrm{CD} 16^{-}, \mathrm{CD} 14^{++} \mathrm{CD} 16^{+}$, and $\mathrm{CD} 14^{+} \mathrm{CD} 16^{++}$. In accordance with animal studies, the mainly pro-inflammatory $\mathrm{CD} 14^{++} \mathrm{CD} 16^{+}$monocytes were associated with an increased risk of cardiovascular events and atherosclerotic plaque instability $[198,199]$.

Hypercholesterolemia has been recognized since long as a central risk factor for the initiation and progression of atherosclerotic lesions [9], thus it is noteworthy that cholesterol and AA metabolism are interrelated. The latter was demonstrated by the inhibition of the 5-LOX pathway by the hydroxymethylglutaryl-CoA reductase antagonist atorvastatin, and the alteration of cholesterol homeostasis by the COX inhibitor aspirin. Specifically, aspirin induces the bile salt export pump Abcb11 and supports reverse cholesterol transport from atherosclerotic lesions to the liver for their subsequent biliary excretion [200,201]. Chronic hypercholesterolemia results in the sub-endothelial deposition of oxidized cholesterol-rich lipoproteins, which are involved in the recruitment and activation of macrophages, and generation of foam cells.

As previously mentioned, foam cells persist in the vessel wall and contribute to local inflammation and atherosclerotic lesion progression [107,110,111]. Additionally, PMNs foster plaque progression via pro-inflammatory functions and the production of reactive oxygen and 
nitrogen intermediates $[105,202,203]$. Interestingly, the PMN derived peptide S100A8 was found to orchestrate myelopoiesis and promote the recruitment of monocytes to atherosclerotic lesions [204]. AA metabolites are also implicated in this process as they contribute to chemotaxis, inflammation, and are involved in efferocytosis. Efferocytosis, especially the clearance of PMNs and foam cells, is of major importance for the resolution of inflammation, and its impairment leads to the progression of atherosclerotic lesions. Efferocytosis is actively supported by pro-resolving mediators, especially SPMs, which compromise various groups of eicosanoids: (1) Lipoxins produced by LOX enzymes, (2) E-resolvins derived from EPA, and (3) metabolites of DHA such as D-resolvins, protectins, and maresins [94,205]. In addition to their supportive role in efferocytosis, SPMs exert anti-inflammatory effects via inhibition of pro-inflammatory macrophage cytokine production and atheroprotective actions via induction of adhesion receptor expression in endothelial cells and reduction of intimal hyperplasia following vascular injury [206]. In this context, the AA derivative LXA4 is of special interest. LXA4 is a pro-resolving lipid mediator, which is mainly produced following the so-called "eicosanoid class switch". This term was implemented to describe a switch in enzymatic AA processing, which is typically found in the resolution phase of inflammation $[16,205]$. During the early phase of inflammation, AA is predominantly metabolized via 5-LOX, which produces pro-inflammatory LTs including LTB4, whereas in the late phase PGs, such as PGE2, enhance 15-LOX expression, followed by a switch from LTB4 synthesis to 5-LOX and 15-LOX-mediated LXA4 production. Notably, in vivo LXA4 levels are decreased in patients with peripheral and coronary atherosclerosis [207], and overexpression of 12-LOX and 15-LOX in macrophages of atherosclerotic apoE deficient mice increases LXA4 production and hampers atherosclerotic lesion development [107]. This atheroprotective effect of LXA4 has been linked to its anti-inflammatory capacity, as it impairs the production of various pro-inflammatory cytokines, stops neutrophil chemotaxis, and induces pro-resolving macrophages functions $[107,208,209]$. Interestingly, aspirin enhances LXA4 production ensued by alleviation of atherosclerotic lesions in apoE deficient mice [210]. Notably, 12-LOX and 15-LOX are also key enzymes in the production of SPMs other than LXA4, thus the observed effects in this model may not be exclusively confined to LXA4. In addition, data on the atheroprotective functions of 12/15-LOX derived metabolites remains rather controversial, as earlier studies reported that 12/15-LOX- apoE- double-deficient mice ( $\left.\mathrm{apoE}^{-/-} / 12 / 15-\mathrm{LOX}^{-/-}\right)$are less prone to atherogenesis, as compared to apoE-deficient littermates with fully functional 12/15-LOX [104].

In contrast to the mainly atheroprotective functions found for lipoxins, LTs affect the progression of hyperlipidemia-dependent vascular disease and are associated with atherogenesis, cardiovascular disease, myocardial infarction, and stroke [101,211]. LTs are AA metabolites derived from the 5-LOX pathway and exert their actions through binding to G-protein-coupled cell surface receptors. LTB4 interacts with leukotriene B4 receptor 1 and 2 (leukotriene B4 receptor 1 (LTB4R) and leukotriene B4 receptor 2 (LTB4R2), also known as BLT1 and BLT2), whereas cysteinyl leukotrienes (CysLTs), such as leukotriene C4 (LTC4), leukotriene D4 (LTD4), and leukotriene F4 (LTF4), bind to cysteinyl leukotriene receptor 1 and 2 (CYSLTR1 and CYSLTR2), respectively [212]. The CysLT leukotriene E4 (LTE4) displays a specific receptor, termed cysteinyl leukotriene receptor E (CYSLTRE) [213], and also interacts with the COX2 receptor PPAR $\gamma$, and the purinergic receptor P2Y12 (P2RY12) [214,215]. LTB4 and CysLTs exert various effects on the cardiovascular system, including their negative inotropic action on the myocardium, the reduction of coronary perfusion via vessel contraction, the stimulation of arterial smooth muscle cell (SMC) proliferation and induction of the expression of adhesion and pro-coagulatory factors, such as von Willebrand factor (vWF), P-selectin and platelet-activating factor (PAF) [216-220]. Therefore, LTB4 and CysLTs are likely to contribute to the pathophysiology of atherosclerosis and myocardial dysfunction. Accordingly, an enhanced activity of the 5-LOX pathway was found in atherosclerotic lesions [221,222], and the quantity of 5-LOX positive cells correlates with the progression of atherosclerotic lesions and plaque stability $[222,223]$. Blockade of LTB4 receptors protects against the development of atherosclerosis in apoE-deficient mice [224], and the endothelial overexpression of CYSLTR2 increases vascular permeability, myocardial ischemia/reperfusion damage, 
and cardiomyocyte apoptosis in peri-infarct areas [54,225,226]. Notably, 5-LOX expression in atherosclerotic plaques is mainly restricted to local macrophages, and 5-LOX positive macrophages were implicated in the development of aortic aneurysms in apoE-deficient mice when kept on an atherogenic diet [211].

Genetic variations of key enzymes for LTB4 production, namely 5-LOX, 5-LOX activating protein (FLAP), and leukotriene A4 hydrolase (LTA4H), as well as alterations in their functionality are linked to atherosclerosis susceptibility and the prevalence of cardiovascular events [227-232]. Most recently, it was shown that LTB4 fosters the recruitment of neutrophils to atherosclerotic plaques and contributes to plaque destabilization [233]. In line with the pro-atherogenic effects of LTs, they are implicated in myocardial ischemia and reperfusion injury. Accordingly, endothelial cysteinyl leukotriene 2 receptor (CYSLTR2) expression within the heart and vasculature is induced by ischemia/reperfusion injury [234]. Interaction of LTs with CYSLTR2 increases vascular permeability and amplifies the extent of the myocardial injury, and high levels of CYSLTR2 expression in the heart and vessels have been linked to a detrimental outcome in murine ischemia/reperfusion models [234]. In line with this, pharmacological blockade of LTBR4 reduces infarct size in a murine model of myocardial ischemia/reperfusion injury [235], and the CYSLTR antagonist montelukast, which is mainly used in the treatment of asthma and allergic rhinitis, was recently evaluated for its possible cardio-protective capacities. Interestingly, both animal models and clinical trials demonstrated a preventive role of montelukast against the development of atherosclerosis and suggested a cardioprotective function [236-240].

The COX pathway is one of the major treatment targets in atherosclerotic and ischemic heart disease because it affects major pathophysiological features of these diseases, including platelet aggregation, vessel wall tension, and inflammatory processes in atherosclerotic lesions [102]. The anti-inflammatory and anti-thrombotic features of aspirin, the only known irreversible inhibitor of platelet COX1, are primarily related to the suppression of PG and TXA2 synthesis [241]. In this context, a recent study demonstrated that the COX1/TXA2 pathway is a relevant contributor to vascular hypercontractility in atherosclerotic apoE deficient mice, and its pharmacological inhibition improves endothelial function [242]. Despite being a well-established therapy in cardiovascular disease, some aspects of aspirin treatment warrant further investigation, as reflected by a recent analysis demonstrating an interaction of body weight with the effectiveness of aspirin to prevent cardiovascular events [243]. Notably, aspirin is the only known non-steroidal anti-inflammatory drug (NSAID) with cardioprotective effects. On the contrary, NSAIDs with COX2 inhibitory features increase the cardiovascular risk, which is mainly attributed to their blockage of prostacyclin production [244,245]. Recently, a new drug class, which blocks both the COX1/2 and 5-LOX pathway in a balanced fashion, is evaluated in clinical trials and may present and additional treatment option for cancer, inflammatory, and cardiovascular diseases [246].

The hepatic CYP450 enzyme family is also linked to the pathophysiology of atherosclerosis [66]. The CYP450 enzymes have a well-established function in the regulation of systemic blood pressure, as EETs exert vasodilatory effects, and are implicated in cardiovascular and renal disease [66,247]. Accordingly, the pharmacological inhibition of the soluble epoxide hydrolase (sEH), a key enzyme in the dissipation of EETs, exhibits antihypertensive and cardioprotective activity in transgenic rats with angiotensin II-dependent hypertension [248]. As previously mentioned, oral administrations of $\mathrm{sEH}$ inhibitors are currently tested in clinical trials and may present a future therapy in patients with cardiovascular diseases and arterial hypertension [249].

Finally, AA metabolites derived from non-enzymatic AA processing, such as isoprostanes may be involved in the pathophysiology of cardiac diseases. For instance, 15-F2c isoprostane activates the PGF $2 \alpha$ receptor and induces hypertrophy in cardiac smooth muscle cells [73]. Still, data on isoprostanes in atherosclerosis and cardiac disease are sparse and urge further elucidation. 


\section{Conclusions and Perspectives}

Metabolic and cardiovascular diseases share the common pathophysiology of unresolving chronic inflammation. AA metabolites are important factors in the initiation and resolution of inflammation and have been linked to the pathophysiology of obesity, DM, NAFLD/NASH, and cardiovascular diseases. The plethora of AA derivatives and their multitudinous implications, and the differential expression and functionality of AA metabolites in various cells and tissues, as well as their transcellular biosynthesis, render the AA metabolism one of the most complex regulatory systems within the human body. It is thus not surprising that many aspects of the AA metabolome still need further investigation, despite extensive scientific progress in the field. The establishment of new methodologies, including real-time and cell-specific lipidomic profiling, commence an opportunity to achieve a better understanding of the complexity of the eicosanoid metabolism and may help to improve current treatment strategies and to establish new approaches to counteract metabolic and cardiovascular diseases.

\section{Methodology}

We collected data and references with PubMed (available online: https://www.ncbi.nlm.nih. gov/pubmed/), Google, and Google Scholar. The following keywords were used for literature search: arachidonic acid, eicosanoids, isoprostanes, cholesterol, phospholipases, cyclooxygenases, leukotrienes, lipoxygenases, CYP450, epoxygenases, obesity, metabolic disease, NAFLD, cardiovascular disease, atherosclerosis, and DM.

Author Contributions: T.S., A.P., and I.T. performed literature research. T.S. prepared the figure. T.S., A.P., M.N., G.W. and I.T. wrote the paper. G.W. and I.T. acquired funding. All authors approved the final version.

Funding: This work was supported by the "Verein zur Förderung von Forschung und Weiterbildung in Infektiologie und Immunologie", Innsbruck, Austria (G.W.), Institute Mérieux Research Grants (I.T.), and the Christian Doppler Society, Austria (G.W.).

Conflicts of Interest: The authors declare no conflict of interest.

$\begin{array}{ll}\text { Abbreviations } \\ \% \text { Percent of energy } \\ \text { AA } & \text { Arachidonic acid } \\ \text { ACSL1 } & \text { Acyl-CoA synthetase 1 } \\ \text { ALOX; LOX } & \text { Lipoxygenase } \\ \text { apoE } & \text { Apolipoprotein E } \\ \text { BMI } & \text { Body mass index } \\ \text { CB1 } & \text { Cannabinoid type 1 receptor } \\ \text { COX } & \text { Cyclooxygenase } \\ \text { CYP450 } & \text { Cytochrome P450 } \\ \text { CysLTs } & \text { Cysteinyl leukotrienes (LTC4, LTD4, LTE4 and LTF4) } \\ \text { CYSLTR } & \text { Cysteinyl leukotriene receptor } \\ \text { DAG } & \text { Diacylglycerol } \\ \text { DHA } & \text { Docosahexaenoic acid } \\ \text { DM } & \text { Diabetes mellitus } \\ \text { EET } & \text { Epoxyeicosatrienoic acid } \\ \text { EPA } & \text { Eicosapentaenoic acid } \\ \text { FAAH } & \text { Fatty acid amide hydrolase } \\ \text { FFA } & \text { Free fatty acid } \\ \text { HETE } & \text { Hydroxyeicosatetraenoic acid } \\ \text { HPETE } & \text { Hydroperoxyeicosatetraenoic acid } \\ \text { HHT } & \text { 12-Hydroxyheptadecatrienoic acid } \\ \text { LDL } & \text { Low density lipoprotein } \\ \text { LDL-C } & \text { Low density lipoprotein cholesterol } \\ & \end{array}$




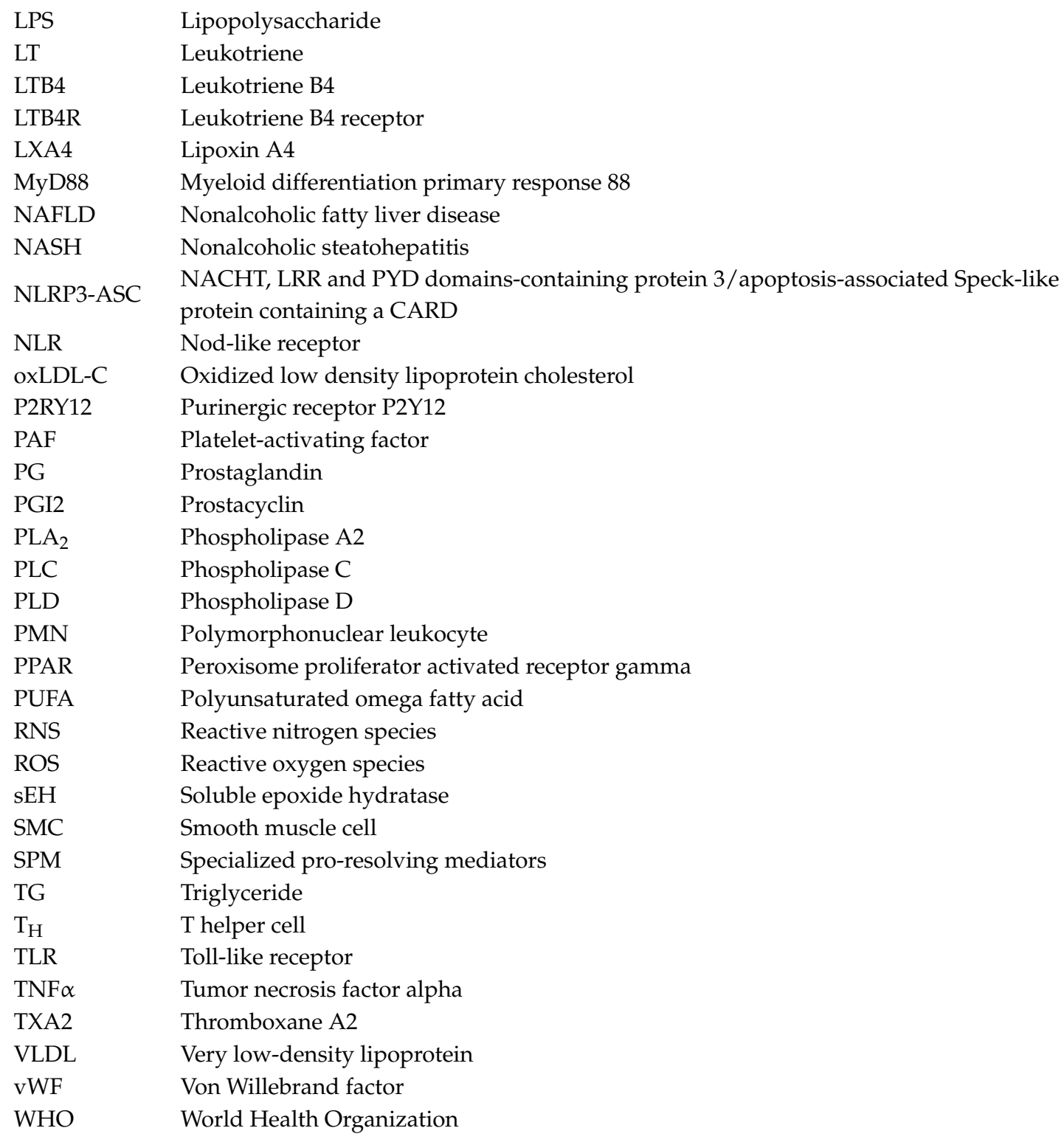

\section{References}

1. Haffner, S.M. The metabolic syndrome: Inflammation, diabetes mellitus, and cardiovascular disease. Am. J. Cardiol. 2006, 97, 3A-11A. [CrossRef] [PubMed]

2. Benjamin, E.J.; Virani, S.S.; Callaway, C.W.; Chamberlain, A.M.; Chang, A.R.; Cheng, S.; Chiuve, S.E.; Cushman, M.; Delling, F.N.; Deo, R.; et al. Heart Disease and Stroke Statistics-2018 Update: A Report from the American Heart Association. Circulation 2018, 137, e67-e492. [CrossRef] [PubMed]

3. Flegal, K.M.; Carroll, M.D.; Kit, B.K.; Ogden, C.L. Prevalence of obesity and trends in the distribution of body mass index among US adults, 1999-2010. JAMA 2012, 307, 491-497. [CrossRef] [PubMed]

4. WHO. Obesity and Overweight: Key Facts. 2018. Available online: http://www.who.int/news-room/factsheets / detail/obesity-and-overweight (accessed on 22 October 2018).

5. Gregor, M.F.; Hotamisligil, G.S. Inflammatory mechanisms in obesity. Annu. Rev. Immunol. 2011, $29,415-445$. [CrossRef] [PubMed]

6. Vanni, E.; Marengo, A.; Mezzabotta, L.; Bugianesi, E. Systemic Complications of Nonalcoholic Fatty Liver Disease: When the Liver Is Not an Innocent Bystander. Semin. Liver Dis. 2015, 35, 236-249. [CrossRef] [PubMed]

7. Loomba, R.; Sanyal, A.J. The global NAFLD epidemic. Nat. Rev. Gastroenterol. Hepatol. 2013, 10, 686-690. [CrossRef] [PubMed] 
8. Ross, R.; Harker, L. Hyperlipidemia and atherosclerosis. Science 1976, 193, 1094-1100. [CrossRef] [PubMed]

9. Clarkson, S.; Newburgh, L.H. The Relation between Atherosclerosis and Ingested Cholesterol in the Rabbit. J. Exp. Med. 1926, 43, 595-612. [CrossRef] [PubMed]

10. Walker, W.J. Relationship of adiposity to serum cholesterol and lipoprotein levels and their modification by dietary means. Ann. Intern. Med. 1953, 39, 705-716. [PubMed]

11. Ross, R. Atherosclerosis—an inflammatory disease. N. Engl. J. Med. 1999, 340, 115-126. [CrossRef] [PubMed]

12. Bennett, M.; Gilroy, D.W. Lipid Mediators in Inflammation. Microbiol. Spectr. 2016, 4. [CrossRef]

13. Hotamisligil, G.S. Inflammation and metabolic disorders. Nature 2006, 444, 860-867. [CrossRef] [PubMed]

14. Serhan, C.N. Inflammation. Signalling the fat controller. Nature 1996, 384, 23-24. [CrossRef] [PubMed]

15. Saltiel, A.R.; Olefsky, J.M. Inflammatory mechanisms linking obesity and metabolic disease. J. Clin. Investig. 2017, 127, 1-4. [CrossRef] [PubMed]

16. Dennis, E.A.; Norris, P.C. Eicosanoid storm in infection and inflammation. Nat. Rev. Immunol. 2015, 15, 511-523. [CrossRef] [PubMed]

17. Hanna, V.S.; Hafez, E.A.A. Synopsis of arachidonic acid metabolism: A review. J. Adv. Res. 2018, 11, $23-32$. [CrossRef] [PubMed]

18. National Center for Biotechnology Information: Pubchem. 5,8,11,14-Eicosatetraenoic Acid. Available online: https:/ / pubchem.ncbi.nlm.nih.gov/ compound/5312542\#section=Top (accessed on 22 October 2018).

19. Rich, M.R. Conformational analysis of arachidonic and related fatty acids using molecular dynamics simulations. Biochim. Biophys. Acta 1993, 1178, 87-96. [CrossRef]

20. Weller, P.F. Leukocyte Lipid Bodies-Structure and Function as "Eicosasomes". Trans. Am. Clin. Climatol. Assoc. 2016, 127, 328-340. [PubMed]

21. McArthur, M.J.; Atshaves, B.P.; Frolov, A.; Foxworth, W.D.; Kier, A.B.; Schroeder, F. Cellular uptake and intracellular trafficking of long chain fatty acids. J. Lipid Res. 1999, 40, 1371-1383. [PubMed]

22. Taber, L.; Chiu, C.H.; Whelan, J. Assessment of the arachidonic acid content in foods commonly consumed in the American diet. Lipids 1998, 33, 1151-1157. [CrossRef] [PubMed]

23. Sinclair, A.J.; Johnson, L.; O'Dea, K.; Holman, R.T. Diets rich in lean beef increase arachidonic acid and long-chain omega 3 polyunsaturated fatty acid levels in plasma phospholipids. Lipids 1994, 29, 337-343. [CrossRef] [PubMed]

24. Li, D.; Ng, A.; Mann, N.J.; Sinclair, A.J. Contribution of meat fat to dietary arachidonic acid. Lipids 1998, 33, 437-440. [CrossRef] [PubMed]

25. Lee, J.M.; Lee, H.; Kang, S.; Park, W.J. Fatty Acid Desaturases, Polyunsaturated Fatty Acid Regulation, and Biotechnological Advances. Nutrients 2016, 8, 23. [CrossRef] [PubMed]

26. Dennis, E.A.; Cao, J.; Hsu, Y.H.; Magrioti, V.; Kokotos, G. Phospholipase A2 enzymes: Physical structure, biological function, disease implication, chemical inhibition, and therapeutic intervention. Chem. Rev. 2011, 111, 6130-6185. [CrossRef] [PubMed]

27. Brash, A.R. Arachidonic acid as a bioactive molecule. J. Clin. Investig. 2001, 107, 1339-1345. [CrossRef] [PubMed]

28. Miki, Y.; Yamamoto, K.; Taketomi, Y.; Sato, H.; Shimo, K.; Kobayashi, T.; Ishikawa, Y.; Ishii, T.; Nakanishi, H.; Ikeda, K.; et al. Lymphoid tissue phospholipase A2 group IID resolves contact hypersensitivity by driving antiinflammatory lipid mediators. J. Exp. Med. 2013, 210, 1217-1234. [CrossRef] [PubMed]

29. Kano, M. Control of synaptic function by endocannabinoid-mediated retrograde signaling. Proc. Jpn. Acad. Ser. B Phys. Biol. Sci. 2014, 90, 235-250. [CrossRef] [PubMed]

30. Ishimoto, T.; Akiba, S.; Sato, T.; Fujii, T. Contribution of phospholipases A2 and D to arachidonic acid liberation and prostaglandin D2 formation with increase in intracellular $\mathrm{Ca}^{2+}$ concentration in rat peritoneal mast cells. FEBS J. 1994, 219, 401-406. [CrossRef]

31. Ahn, K.; McKinney, M.K.; Cravatt, B.F. Enzymatic pathways that regulate endocannabinoid signaling in the nervous system. Chem. Rev. 2008, 108, 1687-1707. [CrossRef] [PubMed]

32. Wlodawer, P.; Samuelsson, B. On the organization and mechanism of prostaglandin synthetase. J. Biol. Chem. 1973, 248, 5673-5678. [PubMed]

33. Smith, W.L.; DeWitt, D.L.; Garavito, R.M. Cyclooxygenases: Structural, cellular, and molecular biology. Annu. Rev. Biochem. 2000, 69, 145-182. [CrossRef] [PubMed]

34. Hartwig, J.H.; Bokoch, G.M.; Carpenter, C.L.; Janmey, P.A.; Taylor, L.A.; Toker, A.; Stossel, T.P. Thrombin receptor ligation and activated Rac uncap actin filament barbed ends through phosphoinositide synthesis in permeabilized human platelets. Cell 1995, 82, 643-653. [CrossRef] 
35. Kabashima, K.; Murata, T.; Tanaka, H.; Matsuoka, T.; Sakata, D.; Yoshida, N.; Katagiri, K.; Kinashi, T.; Tanaka, T.; Miyasaka, M.; et al. Thromboxane A2 modulates interaction of dendritic cells and T cells and regulates acquired immunity. Nat. Immunol. 2003, 4, 694-701. [CrossRef] [PubMed]

36. Cogolludo, A.; Moreno, L.; Bosca, L.; Tamargo, J.; Perez-Vizcaino, F. Thromboxane A2-induced inhibition of voltage-gated $\mathrm{K}+$ channels and pulmonary vasoconstriction: Role of protein kinase Czeta. Circ. Res. 2003, 93, 656-663. [CrossRef] [PubMed]

37. Cheng, K.; Wu, T.J.; Wu, K.K.; Sturino, C.; Metters, K.; Gottesdiener, K.; Wright, S.D.; Wang, Z.; O’Neill, G.; Lai, E.; et al. Antagonism of the prostaglandin D2 receptor 1 suppresses nicotinic acid-induced vasodilation in mice and humans. Proc. Natl. Acad. Sci. USA 2006, 103, 6682-6687. [CrossRef] [PubMed]

38. Taketomi, Y.; Ueno, N.; Kojima, T.; Sato, H.; Murase, R.; Yamamoto, K.; Tanaka, S.; Sakanaka, M.; Nakamura, M.; Nishito, Y.; et al. Mast cell maturation is driven via a group III phospholipase A2-prostaglandin D2-DP1 receptor paracrine axis. Nat. Immunol. 2013, 14, 554-563. [CrossRef] [PubMed]

39. Basu, S. Novel cyclooxygenase-catalyzed bioactive prostaglandin F2alpha from physiology to new principles in inflammation. Med. Res. Rev. 2007, 27, 435-468. [CrossRef] [PubMed]

40. Brock, T.G.; McNish, R.W.; Peters-Golden, M. Arachidonic acid is preferentially metabolized by cyclooxygenase-2 to prostacyclin and prostaglandin E2. J. Biol. Chem. 1999, 274, 11660-11666. [CrossRef] [PubMed]

41. Stockley, P. Female multiple mating behaviour, early reproductive failure and litter size variation in mammals. Proc. Biol. Sci. 2003, 270, 271-278. [CrossRef] [PubMed]

42. Howe, L.R.; Chang, S.H.; Tolle, K.C.; Dillon, R.; Young, L.J.; Cardiff, R.D.; Newman, R.A.; Yang, P.; Thaler, H.T.; Muller, W.J.; et al. HER2/neu-induced mammary tumorigenesis and angiogenesis are reduced in cyclooxygenase-2 knockout mice. Cancer Res. 2005, 65, 10113-10119. [CrossRef] [PubMed]

43. Teismann, P.; Tieu, K.; Choi, D.K.; Wu, D.C.; Naini, A.; Hunot, S.; Vila, M.; Jackson-Lewis, V.; Przedborski, S. Cyclooxygenase-2 is instrumental in Parkinson's disease neurodegeneration. Proc. Natl. Acad. Sci. USA 2003, 100, 5473-5478. [CrossRef] [PubMed]

44. Minami, T.; Nakano, H.; Kobayashi, T.; Sugimoto, Y.; Ushikubi, F.; Ichikawa, A.; Narumiya, S.; Ito, S. Characterization of EP receptor subtypes responsible for prostaglandin E2-induced pain responses by use of EP1 and EP3 receptor knockout mice. Br. J. Pharmacol. 2001, 133, 438-444. [CrossRef] [PubMed]

45. Shinomiya, S.; Naraba, H.; Ueno, A.; Utsunomiya, I.; Maruyama, T.; Ohuchida, S.; Ushikubi, F.; Yuki, K.; Narumiya, S.; Sugimoto, Y.; et al. Regulation of TNFalpha and interleukin-10 production by prostaglandins I(2) and E(2): Studies with prostaglandin receptor-deficient mice and prostaglandin E-receptor subtype-selective synthetic agonists. Biochem. Pharmacol. 2001, 61, 1153-1160. [CrossRef]

46. Murata, T.; Ushikubi, F.; Matsuoka, T.; Hirata, M.; Yamasaki, A.; Sugimoto, Y.; Ichikawa, A.; Aze, Y.; Tanaka, T.; Yoshida, N.; et al. Altered pain perception and inflammatory response in mice lacking prostacyclin receptor. Nature 1997, 388, 678-682. [CrossRef] [PubMed]

47. Weiss, H.J.; Turitto, V.T. Prostacyclin (prostaglandin I2, PGI2) inhibits platelet adhesion and thrombus formation on subendothelium. Blood 1979, 53, 244-250. [PubMed]

48. Chandrasekharan, N.V.; Dai, H.; Roos, K.L.; Evanson, N.K.; Tomsik, J.; Elton, T.S.; Simmons, D.L. COX-3, a cyclooxygenase-1 variant inhibited by acetaminophen and other analgesic/antipyretic drugs: Cloning, structure, and expression. Proc. Natl. Acad. Sci. USA 2002, 99, 13926-13931. [CrossRef] [PubMed]

49. Powell, W.S.; Rokach, J. Biosynthesis, biological effects, and receptors of hydroxyeicosatetraenoic acids (HETEs) and oxoeicosatetraenoic acids (oxo-ETEs) derived from arachidonic acid. Biochim. Biophys. Acta 2015, 1851, 340-355. [CrossRef] [PubMed]

50. Samuelsson, B. Leukotrienes: Mediators of immediate hypersensitivity reactions and inflammation. Science 1983, 220, 568-575. [CrossRef] [PubMed]

51. Lammermann, T.; Afonso, P.V.; Angermann, B.R.; Wang, J.M.; Kastenmuller, W.; Parent, C.A.; Germain, R.N. Neutrophil swarms require LTB4 and integrins at sites of cell death in vivo. Nature 2013, 498, 371-375. [CrossRef] [PubMed]

52. Bray, M.A.; Cunningham, F.M.; Ford-Hutchinson, A.W.; Smith, M.J. Leukotriene B4: A mediator of vascular permeability. Br. J. Pharmacol. 1981, 72, 483-486. [CrossRef] [PubMed]

53. Iizuka, Y.; Okuno, T.; Saeki, K.; Uozaki, H.; Okada, S.; Misaka, T.; Sato, T.; Toh, H.; Fukayama, M.; Takeda, N.; et al. Protective role of the leukotriene B4 receptor BLT2 in murine inflammatory colitis. FASEB J. 2010, 24, 4678-4690. [CrossRef] [PubMed] 
54. Moos, M.P.; Mewburn, J.D.; Kan, F.W.; Ishii, S.; Abe, M.; Sakimura, K.; Noguchi, K.; Shimizu, T.; Funk, C.D. Cysteinyl leukotriene 2 receptor-mediated vascular permeability via transendothelial vesicle transport. FASEB J. 2008, 22, 4352-4362. [CrossRef] [PubMed]

55. Brash, A.R.; Boeglin, W.E.; Chang, M.S. Discovery of a second 15S-lipoxygenase in humans. Proc. Natl. Acad. Sci. USA 1997, 94, 6148-6152. [CrossRef] [PubMed]

56. Zhu, D.; Ran, Y. Role of 15-lipoxygenase/15-hydroxyeicosatetraenoic acid in hypoxia-induced pulmonary hypertension. J. Physiol. Sci. 2012, 62, 163-172. [CrossRef] [PubMed]

57. Romano, M.; Cianci, E.; Simiele, F.; Recchiuti, A. Lipoxins and aspirin-triggered lipoxins in resolution of inflammation. Eur. J. Pharmacol. 2015, 760, 49-63. [CrossRef] [PubMed]

58. Feltenmark, S.; Gautam, N.; Brunnstrom, A.; Griffiths, W.; Backman, L.; Edenius, C.; Lindbom, L.; Bjorkholm, M.; Claesson, H.E. Eoxins are proinflammatory arachidonic acid metabolites produced via the 15-lipoxygenase-1 pathway in human eosinophils and mast cells. Proc. Natl. Acad. Sci. USA 2008, 105, 680-685. [CrossRef] [PubMed]

59. Hwang, S.W.; Cho, H.; Kwak, J.; Lee, S.Y.; Kang, C.J.; Jung, J.; Cho, S.; Min, K.H.; Suh, Y.G.; Kim, D.; et al. Direct activation of capsaicin receptors by products of lipoxygenases: Endogenous capsaicin-like substances. Proc. Natl. Acad. Sci. USA 2000, 97, 6155-6160. [CrossRef] [PubMed]

60. Huang, J.T.; Welch, J.S.; Ricote, M.; Binder, C.J.; Willson, T.M.; Kelly, C.; Witztum, J.L.; Funk, C.D.; Conrad, D.; Glass, C.K. Interleukin-4-dependent production of PPAR-gamma ligands in macrophages by 12/15-lipoxygenase. Nature 1999, 400, 378-382. [CrossRef] [PubMed]

61. Chavis, C.; Vachier, I.; Godard, P.; Bousquet, J.; Chanez, P. Lipoxins and other arachidonate derived mediators in bronchial asthma. Thorax 2000, 55, S38-S41. [CrossRef] [PubMed]

62. Serhan, C.N. Lipoxins and aspirin-triggered 15-epi-lipoxins are the first lipid mediators of endogenous anti-inflammation and resolution. Prostaglandins Leukot Essent Fatty Acids 2005, 73, 141-162. [CrossRef] [PubMed]

63. Ng, V.Y.; Huang, Y.; Reddy, L.M.; Falck, J.R.; Lin, E.T.; Kroetz, D.L. Cytochrome P450 eicosanoids are activators of peroxisome proliferator-activated receptor alpha. Drug Metab. Dispos. 2007, 35, 1126-1134. [CrossRef] [PubMed]

64. Liu, Y.; Zhang, Y.; Schmelzer, K.; Lee, T.S.; Fang, X.; Zhu, Y.; Spector, A.A.; Gill, S.; Morisseau, C.; Hammock, B.D.; et al. The antiinflammatory effect of laminar flow: The role of PPARgamma, epoxyeicosatrienoic acids, and soluble epoxide hydrolase. Proc. Natl. Acad. Sci. USA 2005, 102, 16747-16752. [CrossRef] [PubMed]

65. Inceoglu, B.; Schmelzer, K.R.; Morisseau, C.; Jinks, S.L.; Hammock, B.D. Soluble epoxide hydrolase inhibition reveals novel biological functions of epoxyeicosatrienoic acids (EETs). Prostaglandins Other Lipid Mediat. 2007, 82, 42-49. [CrossRef] [PubMed]

66. Fan, F.; Muroya, Y.; Roman, R.J. Cytochrome P450 eicosanoids in hypertension and renal disease. Curr. Opin. Nephrol. Hypertens. 2015, 24, 37-46. [CrossRef] [PubMed]

67. Ueda, N.; Tsuboi, K.; Uyama, T. Metabolism of endocannabinoids and related N-acylethanolamines: Canonical and alternative pathways. FEBS J. 2013, 280, 1874-1894. [CrossRef] [PubMed]

68. Izzo, A.A.; Deutsch, D.G. Unique pathway for anandamide synthesis and liver regeneration. Proc. Natl. Acad. Sci. USA 2011, 108, 6339-6340. [CrossRef] [PubMed]

69. Mukhopadhyay, B.; Cinar, R.; Yin, S.; Liu, J.; Tam, J.; Godlewski, G.; Harvey-White, J.; Mordi, I.; Cravatt, B.F.; Lotersztajn, S.; et al. Hyperactivation of anandamide synthesis and regulation of cell-cycle progression via cannabinoid type 1 (CB1) receptors in the regenerating liver. Proc. Natl. Acad. Sci. USA 2011, 108, 6323-6328. [CrossRef] [PubMed]

70. Morrow, J.D.; Hill, K.E.; Burk, R.F.; Nammour, T.M.; Badr, K.F.; Roberts, L.J., 2nd. A series of prostaglandin F2-like compounds are produced in vivo in humans by a non-cyclooxygenase, free radical-catalyzed mechanism. Proc. Natl. Acad. Sci. USA 1990, 87, 9383-9387. [CrossRef] [PubMed]

71. Balazy, M.; Poff, C.D. Biological nitration of arachidonic acid. Curr. Vasc. Pharmacol. 2004, 2, 81-93. [CrossRef] [PubMed]

72. Fam, S.S.; Morrow, J.D. The isoprostanes: Unique products of arachidonic acid oxidation-a review. Curr. Med. Chem. 2003, 10, 1723-1740. [CrossRef] [PubMed]

73. Kunapuli, P.; Lawson, J.A.; Rokach, J.A.; Meinkoth, J.L.; FitzGerald, G.A. Prostaglandin F2alpha (PGF2alpha) and the isoprostane, 8, 12-iso-isoprostane F2alpha-III, induce cardiomyocyte hypertrophy. Differential activation of downstream signaling pathways. J. Biol. Chem. 1998, 273, 22442-22452. [CrossRef] [PubMed] 
74. Trostchansky, A.; Bonilla, L.; Thomas, C.P.; O’Donnell, V.B.; Marnett, L.J.; Radi, R.; Rubbo, H. Nitroarachidonic acid, a novel peroxidase inhibitor of prostaglandin endoperoxide $H$ synthases 1 and 2. J. Biol. Chem. 2011, 286, 12891-12900. [CrossRef] [PubMed]

75. Tallima, H.; El Ridi, R. Arachidonic acid: Physiological roles and potential health benefits-A review. J. Adv. Res. 2018, 11, 33-41. [CrossRef] [PubMed]

76. Kang, J.X.; Leaf, A. Prevention of fatal cardiac arrhythmias by polyunsaturated fatty acids. Am. J. Clin. Nutr. 2000, 71, 202S-207S. [CrossRef] [PubMed]

77. Kawanabe, A.; Okamura, Y. Effects of unsaturated fatty acids on the kinetics of voltage-gated proton channels heterologously expressed in cultured cells. J. Physiol. 2016, 594, 595-610. [CrossRef] [PubMed]

78. Henderson, L.M.; Thomas, S.; Banting, G.; Chappell, J.B. The arachidonate-activatable, NADPH oxidase-associated $\mathrm{H}^{+}$channel is contained within the multi-membrane-spanning $\mathrm{N}$-terminal region of gp91-phox. Biochem. J. 1997, 325, 701-705. [CrossRef] [PubMed]

79. Mitjavila, M.T.; Moreno, J.J. The effects of polyphenols on oxidative stress and the arachidonic acid cascade. Implications for the prevention/treatment of high prevalence diseases. Biochem. Pharmacol. 2012, 84, 1113-1122. [CrossRef] [PubMed]

80. Perez, R.; Matabosch, X.; Llebaria, A.; Balboa, M.A.; Balsinde, J. Blockade of arachidonic acid incorporation into phospholipids induces apoptosis in U937 promonocytic cells. J. Lipid Res. 2006, 47, 484-491. [CrossRef] [PubMed]

81. Das, U.N. Gamma-linolenic acid, arachidonic acid, and eicosapentaenoic acid as potential anticancer drugs. Nutrition 1990, 6, 429-434. [PubMed]

82. Furukawa, S.; Fujita, T.; Shimabukuro, M.; Iwaki, M.; Yamada, Y.; Nakajima, Y.; Nakayama, O.; Makishima, M.; Matsuda, M.; Shimomura, I. Increased oxidative stress in obesity and its impact on metabolic syndrome. J. Clin. Investig. 2004, 114, 1752-1761. [CrossRef] [PubMed]

83. Abdelmagid, S.A.; Clarke, S.E.; Nielsen, D.E.; Badawi, A.; El-Sohemy, A.; Mutch, D.M.; Ma, D.W. Comprehensive profiling of plasma fatty acid concentrations in young healthy Canadian adults. PLoS ONE 2015, 10, e0116195. [CrossRef] [PubMed]

84. Pompeia, C.; Lima, T.; Curi, R. Arachidonic acid cytotoxicity: Can arachidonic acid be a physiological mediator of cell death? Cell Biochem. Funct. 2003, 21, 97-104. [CrossRef] [PubMed]

85. Innis, S.M. Impact of maternal diet on human milk composition and neurological development of infants. Am. J. Clin. Nutr. 2014, 99, 734S-741S. [CrossRef] [PubMed]

86. Wang, L.; Folsom, A.R.; Eckfeldt, J.H. Plasma fatty acid composition and incidence of coronary heart disease in middle aged adults: The Atherosclerosis Risk in Communities (ARIC) Study. Nutr. Metab. Cardiovasc. Dis. 2003, 13, 256-266. [CrossRef]

87. Salonen, J.T.; Salonen, R.; Penttila, I.; Herranen, J.; Jauhiainen, M.; Kantola, M.; Lappetelainen, R.; Maenpaa, P.H.; Alfthan, G.; Puska, P. Serum fatty acids, apolipoproteins, selenium and vitamin antioxidants and the risk of death from coronary artery disease. Am. J. Cardiol. 1985, 56, 226-231. [CrossRef]

88. Miettinen, T.A.; Naukkarinen, V.; Huttunen, J.K.; Mattila, S.; Kumlin, T. Fatty-acid composition of serum lipids predicts myocardial infarction. Br. Med. J. (Clin Res. Ed.) 1982, 285, 993-996. [CrossRef]

89. Goetzl, E.J.; An, S.; Smith, W.L. Specificity of expression and effects of eicosanoid mediators in normal physiology and human diseases. FASEB J. 1995, 9, 1051-1058. [CrossRef] [PubMed]

90. Folco, G.; Murphy, R.C. Eicosanoid transcellular biosynthesis: From cell-cell interactions to in vivo tissue responses. Pharmacol. Rev. 2006, 58, 375-388. [CrossRef] [PubMed]

91. Norris, P.C.; Reichart, D.; Dumlao, D.S.; Glass, C.K.; Dennis, E.A. Specificity of eicosanoid production depends on the TLR-4-stimulated macrophage phenotype. J. Leukoc. Biol. 2011, 90, 563-574. [CrossRef] [PubMed]

92. Astarita, G.; Kendall, A.C.; Dennis, E.A.; Nicolaou, A. Targeted lipidomic strategies for oxygenated metabolites of polyunsaturated fatty acids. Biochim. Biophys. Acta 2015, 1851, 456-468. [CrossRef] [PubMed]

93. Chiang, N.; Fredman, G.; Backhed, F.; Oh, S.F.; Vickery, T.; Schmidt, B.A.; Serhan, C.N. Infection regulates pro-resolving mediators that lower antibiotic requirements. Nature 2012, 484, 524-528. [CrossRef] [PubMed]

94. Serhan, C.N. Pro-resolving lipid mediators are leads for resolution physiology. Nature 2014, 510, 92-101. [CrossRef] [PubMed]

95. Tang, Y.; Zhang, M.J.; Hellmann, J.; Kosuri, M.; Bhatnagar, A.; Spite, M. Proresolution therapy for the treatment of delayed healing of diabetic wounds. Diabetes 2013, 62, 618-627. [CrossRef] [PubMed]

96. Spite, M.; Claria, J.; Serhan, C.N. Resolvins, specialized proresolving lipid mediators, and their potential roles in metabolic diseases. Cell Metab. 2014, 19, 21-36. [CrossRef] [PubMed] 
97. Gilroy, D.W. Eicosanoids and the endogenous control of acute inflammatory resolution. Int. J. Biochem. Cell Biol. 2010, 42, 524-528. [CrossRef] [PubMed]

98. Serhan, C.N.; Drazen, J.M. Antiinflammatory potential of lipoxygenase-derived eicosanoids: A molecular switch at 5 and 15 positions? J. Clin. Investig. 1997, 99, 1147-1148. [CrossRef] [PubMed]

99. Nathan, C.; Ding, A. Nonresolving inflammation. Cell. 2010, 140, 871-882. [CrossRef] [PubMed]

100. Hardwick, J.P.; Eckman, K.; Lee, Y.K.; Abdelmegeed, M.A.; Esterle, A.; Chilian, W.M.; Chiang, J.Y.; Song, B.J. Eicosanoids in metabolic syndrome. Adv. Pharmacol. 2013, 66, 157-266. [PubMed]

101. Back, M.; Hansson, G.K. Leukotriene receptors in atherosclerosis. Ann. Med. 2006, 38, 493-502. [CrossRef] [PubMed]

102. Mitchell, J.A.; Kirkby, N.S. Eicosanoids, prostacyclin and cyclooxygenase in the cardiovascular system. Br. J. Pharmacol. 2018. [CrossRef] [PubMed]

103. Tabas, I.; Glass, C.K. Anti-inflammatory therapy in chronic disease: Challenges and opportunities. Science 2013, 339, 166-172. [CrossRef] [PubMed]

104. Cyrus, T.; Witztum, J.L.; Rader, D.J.; Tangirala, R.; Fazio, S.; Linton, M.F.; Funk, C.D. Disruption of the 12/15-lipoxygenase gene diminishes atherosclerosis in apo E-deficient mice. J. Clin. Investig. 1999, 103, 1597-1604. [CrossRef] [PubMed]

105. Della Bona, R.; Cardillo, M.T.; Leo, M.; Biasillo, G.; Gustapane, M.; Trotta, F.; Biasucci, L.M. Polymorphonuclear neutrophils and instability of the atherosclerotic plaque: A causative role? Inflamm. Res. 2013, 62, 537-550. [CrossRef] [PubMed]

106. Filep, J.G.; Zouki, C.; Petasis, N.A.; Hachicha, M.; Serhan, C.N. Anti-inflammatory actions of lipoxin A(4) stable analogs are demonstrable in human whole blood: Modulation of leukocyte adhesion molecules and inhibition of neutrophil-endothelial interactions. Blood 1999, 94, 4132-4142. [PubMed]

107. Merched, A.J.; Ko, K.; Gotlinger, K.H.; Serhan, C.N.; Chan, L. Atherosclerosis: Evidence for impairment of resolution of vascular inflammation governed by specific lipid mediators. FASEB J. 2008, 22, 3595-3606. [CrossRef] [PubMed]

108. Lumeng, C.N.; Saltiel, A.R. Inflammatory links between obesity and metabolic disease. J. Clin. Investig. 2011, 121, 2111-2117. [CrossRef] [PubMed]

109. Lee, S.; Nakahira, K.; Dalli, J.; Siempos, I.I.; Norris, P.C.; Colas, R.A.; Moon, J.S.; Shinohara, M.; Hisata, S.; Howrylak, J.A.; et al. NLRP3 Inflammasome Deficiency Protects against Microbial Sepsis via Increased Lipoxin B4 Synthesis. Am. J. Respir. Crit. Care Med. 2017, 196, 713-726. [CrossRef] [PubMed]

110. Rocha, V.Z.; Libby, P. Obesity, inflammation, and atherosclerosis. Nat. Rev. Cardiol. 2009, 6, 399-409. [CrossRef] [PubMed]

111. Bornfeldt, K.E.; Tabas, I. Insulin resistance, hyperglycemia, and atherosclerosis. Cell metab. 2011, 14, 575-585. [CrossRef] [PubMed]

112. Food and Agriculture Organization of the United Nations (FAO). Fats and Fatty Acids in Human nutrition-Report of An Expert Consultation. 2010. Available online: http://www.who.int/nutrition/ publications/nutrientrequirements/fatsandfattyacids_humannutrition/en/ (accessed on 22 October 2018).

113. Djousse, L.; Akinkuolie, A.O.; Wu, J.H.; Ding, E.L.; Gaziano, J.M. Fish consumption, omega-3 fatty acids and risk of heart failure: A meta-analysis. Clin. Nutr. 2012, 31, 846-853. [CrossRef] [PubMed]

114. Abdelhamid, A.S.; Brown, T.J.; Brainard, J.S.; Biswas, P.; Thorpe, G.C.; Moore, H.J.; Deane, K.H.; AlAbdulghafoor, F.K.; Summerbell, C.D.; Worthington, H.V.; et al. Omega-3 fatty acids for the primary and secondary prevention of cardiovascular disease. Cochrane Database Syst. Rev. 2018, 7, CD003177. [CrossRef] [PubMed]

115. Harris, W.S.; Mozaffarian, D.; Rimm, E.; Kris-Etherton, P.; Rudel, L.L.; Appel, L.J.; Engler, M.M.; Engler, M.B.; Sacks, F. Omega-6 fatty acids and risk for cardiovascular disease: A science advisory from the American Heart Association Nutrition Subcommittee of the Council on Nutrition, Physical Activity, and Metabolism; Council on Cardiovascular Nursing; and Council on Epidemiology and Prevention. Circulation 2009, 119, 902-907. [PubMed]

116. Aung, T.; Halsey, J.; Kromhout, D.; Gerstein, H.C.; Marchioli, R.; Tavazzi, L.; Geleijnse, J.M.; Rauch, B.; Ness, A.; Galan, P.; et al. Associations of Omega-3 Fatty Acid Supplement Use With Cardiovascular Disease Risks: Meta-analysis of 10 Trials Involving 77917 Individuals. JAMA cardiol. 2018, 3, 225-234. [CrossRef] [PubMed] 
117. Vanden Heuvel, J.P. Cardiovascular disease-related genes and regulation by diet. Curr. Atheroscler. Rep. 2009, 11, 448-455. [CrossRef] [PubMed]

118. Vanden Heuvel, J.P. Nutrigenomics and nutrigenetics of omega3 polyunsaturated fatty acids. Prog. Mol. Biol. Transl. Sci. 2012, 108, 75-112. [PubMed]

119. Nguyen, M.T.; Favelyukis, S.; Nguyen, A.K.; Reichart, D.; Scott, P.A.; Jenn, A.; Liu-Bryan, R.; Glass, C.K.; Neels, J.G.; Olefsky, J.M. A subpopulation of macrophages infiltrates hypertrophic adipose tissue and is activated by free fatty acids via Toll-like receptors 2 and 4 and JNK-dependent pathways. J. Biol. Chem. 2007, 282, 35279-35292. [CrossRef] [PubMed]

120. Turinsky, J.; O'Sullivan, D.M.; Bayly, B.P. 1,2-Diacylglycerol and ceramide levels in insulin-resistant tissues of the rat in vivo. J. Biol. Chem. 1990, 265, 16880-16885. [PubMed]

121. Schenk, S.; Saberi, M.; Olefsky, J.M. Insulin sensitivity: Modulation by nutrients and inflammation. J. Clin. Investig. 2008, 118, 2992-3002. [CrossRef] [PubMed]

122. Kennerly, D.A.; Sullivan, T.J.; Sylwester, P.; Parker, C.W. Diacylglycerol metabolism in mast cells: A potential role in membrane fusion and arachidonic acid release. J. Exp. Med. 1979, 150, 1039-1044. [CrossRef] [PubMed]

123. Bajaj, M.; Suraamornkul, S.; Romanelli, A.; Cline, G.W.; Mandarino, L.J.; Shulman, G.I.; DeFronzo, R.A. Effect of a sustained reduction in plasma free fatty acid concentration on intramuscular long-chain fatty Acyl-CoAs and insulin action in type 2 diabetic patients. Diabetes 2005, 54, 3148-3153. [CrossRef] [PubMed]

124. Pickens, C.A.; Sordillo, L.M.; Zhang, C.; Fenton, J.I. Obesity is positively associated with arachidonic acid-derived 5- and 11-hydroxyeicosatetraenoic acid (HETE). Metabolism 2017, 70, 177-191. [CrossRef] [PubMed]

125. Hellmann, J.; Zhang, M.J.; Tang, Y.; Rane, M.; Bhatnagar, A.; Spite, M. Increased saturated fatty acids in obesity alter resolution of inflammation in part by stimulating prostaglandin production. J. Immunol. 2013, 191, 1383-1392. [CrossRef] [PubMed]

126. Borgeson, E.; Johnson, A.M.; Lee, Y.S.; Till, A.; Syed, G.H.; Ali-Shah, S.T.; Guiry, P.J.; Dalli, J.; Colas, R.A.; Serhan, C.N.; et al. Lipoxin A4 Attenuates Obesity-Induced Adipose Inflammation and Associated Liver and Kidney Disease. Cell Metab. 2015, 22, 125-137. [CrossRef] [PubMed]

127. Falagas, M.E.; Kompoti, M. Obesity and infection. Lancet 2006, 6, 438-446. [CrossRef]

128. O’Brien, B.A.; Huang, Y.; Geng, X.; Dutz, J.P.; Finegood, D.T. Phagocytosis of apoptotic cells by macrophages from NOD mice is reduced. Diabetes 2002, 51, 2481-2488. [CrossRef] [PubMed]

129. Li, S.; Sun, Y.; Liang, C.P.; Thorp, E.B.; Han, S.; Jehle, A.W.; Saraswathi, V.; Pridgen, B.; Kanter, J.E.; Li, R.; et al. Defective phagocytosis of apoptotic cells by macrophages in atherosclerotic lesions of ob/ob mice and reversal by a fish oil diet. Circ. Res. 2009, 105, 1072-1082. [CrossRef] [PubMed]

130. Khanna, S.; Biswas, S.; Shang, Y.; Collard, E.; Azad, A.; Kauh, C.; Bhasker, V.; Gordillo, G.M.; Sen, C.K.; Roy, S. Macrophage dysfunction impairs resolution of inflammation in the wounds of diabetic mice. PLoS ONE 2010, 5, e9539. [CrossRef] [PubMed]

131. Hodgson, K.A.; Morris, J.L.; Feterl, M.L.; Govan, B.L.; Ketheesan, N. Altered macrophage function is associated with severe Burkholderia pseudomallei infection in a murine model of type 2 diabetes. Microbes Infect. 2011, 13, 1177-1184. [CrossRef] [PubMed]

132. Canetti, C.; Serezani, C.H.; Atrasz, R.G.; White, E.S.; Aronoff, D.M.; Peters-Golden, M. Activation of phosphatase and tensin homolog on chromosome 10 mediates the inhibition of FcgammaR phagocytosis by prostaglandin E2 in alveolar macrophages. J. Immunol. 2007, 179, 8350-8356. [CrossRef] [PubMed]

133. Li, S.; Wang, Y.; Matsumura, K.; Ballou, L.R.; Morham, S.G.; Blatteis, C.M. The febrile response to lipopolysaccharide is blocked in cyclooxygenase-2(-/-), but not in cyclooxygenase-1(-/-) mice. Brain res. 1999, 825, 86-94. [CrossRef]

134. Collin, M.; Rossi, A.; Cuzzocrea, S.; Patel, N.S.; Di Paola, R.; Hadley, J.; Collino, M.; Sautebin, L.; Thiemermann, C. Reduction of the multiple organ injury and dysfunction caused by endotoxemia in 5-lipoxygenase knockout mice and by the 5-lipoxygenase inhibitor zileuton. J. Leukoc. Biol. 2004, 76, 961-970. [CrossRef] [PubMed]

135. Jeffcoate, W.J.; Harding, K.G. Diabetic foot ulcers. Lancet 2003, 361, 1545-1551. [CrossRef]

136. Wetzler, C.; Kampfer, H.; Stallmeyer, B.; Pfeilschifter, J.; Frank, S. Large and sustained induction of chemokines during impaired wound healing in the genetically diabetic mouse: Prolonged persistence of neutrophils and macrophages during the late phase of repair. J. Investig. Dermatol. 2000, 115, 245-253. [CrossRef] [PubMed] 
137. Berry, E.; Liu, Y.; Chen, L.; Guo, A.M. Eicosanoids: Emerging contributors in stem cell-mediated wound healing. Prostaglandins Other Lipid Mediat. 2017, 132, 17-24. [CrossRef] [PubMed]

138. Brandt, S.L.; Wang, S.; Dejani, N.N.; Klopfenstein, N.; Winfree, S.; Filgueiras, L.; McCarthy, B.P.; Territo, P.R.; Serezani, C.H. Excessive localized leukotriene B4 levels dictate poor skin host defense in diabetic mice. JCI Insight 2018, 3. [CrossRef] [PubMed]

139. Reis, M.B.; Pereira, P.A.T.; Caetano, G.F.; Leite, M.N.; Galvao, A.F.; Paula-Silva, F.W.G.; Frade, M.A.C.; Faccioli, L.H. Lipoxin A4 encapsulated in PLGA microparticles accelerates wound healing of skin ulcers. PLoS ONE 2017, 12, e0182381. [CrossRef] [PubMed]

140. Dejani, N.N.; Brandt, S.L.; Pineros, A.; Glosson-Byers, N.L.; Wang, S.; Son, Y.M.; Medeiros, A.I.; Serezani, C.H. Topical Prostaglandin E Analog Restores Defective Dendritic Cell-Mediated Th17 Host Defense against Methicillin-Resistant Staphylococcus Aureus in the Skin of Diabetic Mice. Diabetes 2016, 65, 3718-3729. [CrossRef] [PubMed]

141. Gyurko, R.; Siqueira, C.C.; Caldon, N.; Gao, L.; Kantarci, A.; Van Dyke, T.E. Chronic hyperglycemia predisposes to exaggerated inflammatory response and leukocyte dysfunction in Akita mice. J. Immunol. 2006, 177, 7250-7256. [CrossRef] [PubMed]

142. Wen, H.; Gris, D.; Lei, Y.; Jha, S.; Zhang, L.; Huang, M.T.; Brickey, W.J.; Ting, J.P. Fatty acid-induced NLRP3-ASC inflammasome activation interferes with insulin signaling. Nat. Immunol. 2011, 12, 408-415. [CrossRef] [PubMed]

143. Eguchi, K.; Manabe, I.; Oishi-Tanaka, Y.; Ohsugi, M.; Kono, N.; Ogata, F.; Yagi, N.; Ohto, U.; Kimoto, M.; Miyake, K.; et al. Saturated fatty acid and TLR signaling link beta cell dysfunction and islet inflammation. Cell Metab. 2012, 15, 518-533. [CrossRef] [PubMed]

144. Shi, H.; Kokoeva, M.V.; Inouye, K.; Tzameli, I.; Yin, H.; Flier, J.S. TLR4 links innate immunity and fatty acid-induced insulin resistance. J. Clin. Investig. 2006, 116, 3015-3025. [CrossRef] [PubMed]

145. Kanter, J.E.; Kramer, F.; Barnhart, S.; Averill, M.M.; Vivekanandan-Giri, A.; Vickery, T.; Li, L.O.; Becker, L.; Yuan, W.; Chait, A.; et al. Diabetes promotes an inflammatory macrophage phenotype and atherosclerosis through acyl-CoA synthetase 1. Proc. Natl. Acad. Sci. USA 2012, 109, E715-E724. [CrossRef] [PubMed]

146. Abrass, C.K.; Hori, M. Alterations in Fc receptor function of macrophages from streptozotocin-induced diabetic rats. J. Immunol. 1984, 133, 1307-1312. [PubMed]

147. Luo, P.; Wang, M.H. Eicosanoids, beta-cell function, and diabetes. Prostaglandins Other Lipid Mediat. 2011, 95, 1-10. [CrossRef] [PubMed]

148. Wang, Y.; Yan, S.; Xiao, B.; Zuo, S.; Zhang, Q.; Chen, G.; Yu, Y.; Chen, D.; Liu, Q.; Liu, Y.; et al. Prostaglandin F2alpha Facilitates Hepatic Glucose Production Through CaMKIIgamma/p38/FOXO1 Signaling Pathway in Fasting and Obesity. Diabetes 2018, 67, 1748-1760. [CrossRef] [PubMed]

149. Bleich, D.; Chen, S.; Zipser, B.; Sun, D.; Funk, C.D.; Nadler, J.L. Resistance to type 1 diabetes induction in 12-lipoxygenase knockout mice. J. Clin. Investig. 1999, 103, 1431-1436. [CrossRef] [PubMed]

150. Imai, Y.; Dobrian, A.D.; Morris, M.A.; Taylor-Fishwick, D.A.; Nadler, J.L. Lipids and immunoinflammatory pathways of beta cell destruction. Diabetologia 2016, 59, 673-678. [CrossRef] [PubMed]

151. McDuffie, M.; Maybee, N.A.; Keller, S.R.; Stevens, B.K.; Garmey, J.C.; Morris, M.A.; Kropf, E.; Rival, C.; Ma, K.; Carter, J.D.; et al. Nonobese diabetic (NOD) mice congenic for a targeted deletion of 12/15-lipoxygenase are protected from autoimmune diabetes. Diabetes 2008, 57, 199-208. [CrossRef] [PubMed]

152. Zafiriou, M.P.; Zelarayan, L.C.; Noack, C.; Renger, A.; Nigam, S.; Siafaka-Kapadai, A. Hepoxilin A(3) protects beta-cells from apoptosis in contrast to its precursor, 12-hydroperoxyeicosatetraenoic acid. Biochim. Biophys. Acta 2011, 1811, 361-369. [CrossRef] [PubMed]

153. Ying, W.; Wollam, J.; Ofrecio, J.M.; Bandyopadhyay, G.; El Ouarrat, D.; Lee, Y.S.; Oh, D.Y.; Li, P.; Osborn, O.; Olefsky, J.M. Adipose tissue B2 cells promote insulin resistance through leukotriene LTB4/LTB4R1 signaling. J. Clin. Investig. 2017, 127, 1019-1030. [CrossRef] [PubMed]

154. Tunaru, S.; Bonnavion, R.; Brandenburger, I.; Preussner, J.; Thomas, D.; Scholich, K.; Offermanns, S. 20-HETE promotes glucose-stimulated insulin secretion in an autocrine manner through FFAR1. Nat. Commun. 2018, 9, 177. [CrossRef] [PubMed]

155. Gangadhariah, M.H.; Dieckmann, B.W.; Lantier, L.; Kang, L.; Wasserman, D.H.; Chiusa, M.; Caskey, C.F.; Dickerson, J.; Luo, P.; Gamboa, J.L.; et al. Cytochrome P450 epoxygenase-derived epoxyeicosatrienoic acids contribute to insulin sensitivity in mice and in humans. Diabetologia 2017, 60, 1066-1075. [CrossRef] [PubMed] 
156. Chen, Y.; Falck, J.R.; Manthati, V.L.; Jat, J.L.; Campbell, W.B. 20-Iodo-14,15-epoxyeicosa-8(Z)-enoyl3-azidophenylsulfonamide: Photoaffinity labeling of a 14,15-epoxyeicosatrienoic acid receptor. Biochemistry 2011, 50, 3840-3848. [CrossRef] [PubMed]

157. Gundala, N.K.V.; Naidu, V.G.M.; Das, U.N. Amelioration of streptozotocin-induced type 2 diabetes mellitus in Wistar rats by arachidonic acid. Biochem. Biophys. Res. Commun. 2018, 496, 105-113. [CrossRef] [PubMed]

158. Borgeson, E.; McGillicuddy, F.C.; Harford, K.A.; Corrigan, N.; Higgins, D.F.; Maderna, P.; Roche, H.M.; Godson, C. Lipoxin A4 attenuates adipose inflammation. FASEB J. 2012, 26, 4287-4294. [CrossRef] [PubMed]

159. Das, U.N. Arachidonic acid and lipoxin A4 as possible endogenous anti-diabetic molecules. Prostaglandins Leukot. Essent. Fatty Acids 2013, 88, 201-210. [CrossRef] [PubMed]

160. Das, U.N. Is There a Role for Bioactive Lipids in the Pathobiology of Diabetes Mellitus? Front. Endocrinol. (Lausanne) 2017, 8, 182. [CrossRef] [PubMed]

161. Wu, J.H.Y.; Marklund, M.; Imamura, F.; Tintle, N.; Ardisson Korat, A.V.; de Goede, J.; Zhou, X.; Yang, W.S.; de Oliveira Otto, M.C.; Kroger, J.; et al. Omega-6 fatty acid biomarkers and incident type 2 diabetes: Pooled analysis of individual-level data for 39740 adults from 20 prospective cohort studies. Lancet Diabetes Endocrinol. 2017, 5, 965-974. [CrossRef]

162. Younossi, Z.M.; Koenig, A.B.; Abdelatif, D.; Fazel, Y.; Henry, L.; Wymer, M. Global epidemiology of nonalcoholic fatty liver disease-Meta-analytic assessment of prevalence, incidence, and outcomes. Hepatology 2016, 64, 73-84. [CrossRef] [PubMed]

163. Mittal, S.; El-Serag, H.B.; Sada, Y.H.; Kanwal, F.; Duan, Z.; Temple, S.; May, S.B.; Kramer, J.R.; Richardson, P.A.; Davila, J.A. Hepatocellular Carcinoma in the Absence of Cirrhosis in United States Veterans is Associated With Nonalcoholic Fatty Liver Disease. Clin. Gastroenterol. Hepatol. 2016, 14, 124-131. [CrossRef] [PubMed]

164. Zoller, H.; Tilg, H. Nonalcoholic fatty liver disease and hepatocellular carcinoma. Metabolism 2016, 65, 1151-1160. [CrossRef] [PubMed]

165. Tilg, H. Adipocytokines in nonalcoholic fatty liver disease: Key players regulating steatosis, inflammation and fibrosis. Curr. Pharm. Des. 2010, 16, 1893-1895. [CrossRef] [PubMed]

166. Bedogni, G.; Miglioli, L.; Masutti, F.; Tiribelli, C.; Marchesini, G.; Bellentani, S. Prevalence of and risk factors for nonalcoholic fatty liver disease: The Dionysos nutrition and liver study. Hepatology 2005, 42, 44-52. [CrossRef] [PubMed]

167. Bozza, P.T.; Bakker-Abreu, I.; Navarro-Xavier, R.A.; Bandeira-Melo, C. Lipid body function in eicosanoid synthesis: An update. Prostaglandins Leukot. Essent. Fatty Acids 2011, 85, 205-213. [CrossRef] [PubMed]

168. McPherson, S.; Hardy, T.; Henderson, E.; Burt, A.D.; Day, C.P.; Anstee, Q.M. Evidence of NAFLD progression from steatosis to fibrosing-steatohepatitis using paired biopsies: Implications for prognosis and clinical management. J. Hepatol. 2015, 62, 1148-1155. [CrossRef] [PubMed]

169. Buzzetti, E.; Pinzani, M.; Tsochatzis, E.A. The multiple-hit pathogenesis of non-alcoholic fatty liver disease (NAFLD). Metabolism 2016, 65, 1038-1048. [CrossRef] [PubMed]

170. Arab, J.P.; Arrese, M.; Trauner, M. Recent Insights into the Pathogenesis of Nonalcoholic Fatty Liver Disease. Annu. Rev. Pathol. 2018, 13, 321-350. [CrossRef] [PubMed]

171. Tilg, H.; Moschen, A.R.; Roden, M. NAFLD and diabetes mellitus. Nat. Rev. Gastroenterol. Hepatol. 2017, 14, 32-42. [CrossRef] [PubMed]

172. Adolph, T.E.; Grander, C.; Grabherr, F.; Tilg, H. Adipokines and Non-Alcoholic Fatty Liver Disease: Multiple Interactions. Int. J. Mol. Sci. 2017, 18.

173. Puri, P.; Wiest, M.M.; Cheung, O.; Mirshahi, F.; Sargeant, C.; Min, H.K.; Contos, M.J.; Sterling, R.K.; Fuchs, M.; Zhou, H.; et al. The plasma lipidomic signature of nonalcoholic steatohepatitis. Hepatology 2009, 50, 1827-1838. [CrossRef] [PubMed]

174. Horrillo, R.; Gonzalez-Periz, A.; Martinez-Clemente, M.; Lopez-Parra, M.; Ferre, N.; Titos, E.; Moran-Salvador, E.; Deulofeu, R.; Arroyo, V.; Claria, J. 5-lipoxygenase activating protein signals adipose tissue inflammation and lipid dysfunction in experimental obesity. J. Immunol. 2010, 184, 3978-3987. [CrossRef] [PubMed]

175. Martinez-Clemente, M.; Ferre, N.; Gonzalez-Periz, A.; Lopez-Parra, M.; Horrillo, R.; Titos, E.; Moran-Salvador, E.; Miquel, R.; Arroyo, V.; Funk, C.D.; et al. 5-lipoxygenase deficiency reduces hepatic inflammation and tumor necrosis factor alpha-induced hepatocyte damage in hyperlipidemia-prone ApoE-null mice. Hepatology 2010, 51, 817-827. [CrossRef] [PubMed] 
176. Spite, M.; Hellmann, J.; Tang, Y.; Mathis, S.P.; Kosuri, M.; Bhatnagar, A.; Jala, V.R.; Haribabu, B. Deficiency of the leukotriene B4 receptor, BLT-1, protects against systemic insulin resistance in diet-induced obesity. J. Immunol. 2011, 187, 1942-1949. [CrossRef] [PubMed]

177. Martinez-Clemente, M.; Ferre, N.; Titos, E.; Horrillo, R.; Gonzalez-Periz, A.; Moran-Salvador, E.; Lopez-Vicario, C.; Miquel, R.; Arroyo, V.; Funk, C.D.; et al. Disruption of the 12/15-lipoxygenase gene (Alox15) protects hyperlipidemic mice from nonalcoholic fatty liver disease. Hepatology 2010, 52, 1980-1991. [CrossRef] [PubMed]

178. Enomoto, N.; Ikejima, K.; Yamashina, S.; Enomoto, A.; Nishiura, T.; Nishimura, T.; Brenner, D.A.; Schemmer, P.; Bradford, B.U.; Rivera, C.A.; et al. Kupffer cell-derived prostaglandin E(2) is involved in alcohol-induced fat accumulation in rat liver. Am. J. Physiol. 2000, 279, G100-G106. [CrossRef] [PubMed]

179. Hui, A.Y.; Dannenberg, A.J.; Sung, J.J.; Subbaramaiah, K.; Du, B.; Olinga, P.; Friedman, S.L. Prostaglandin E2 inhibits transforming growth factor beta 1-mediated induction of collagen alpha 1(I) in hepatic stellate cells. J. Hepatol. 2004, 41, 251-258. [CrossRef] [PubMed]

180. Tsujimoto, S.; Kishina, M.; Koda, M.; Yamamoto, Y.; Tanaka, K.; Harada, Y.; Yoshida, A.; Hisatome, I. Nimesulide, a cyclooxygenase-2 selective inhibitor, suppresses obesity-related non-alcoholic fatty liver disease and hepatic insulin resistance through the regulation of peroxisome proliferator-activated receptor gamma. Int. J. Mol. Med. 2016, 38, 721-728. [CrossRef] [PubMed]

181. Theken, K.N.; Deng, Y.; Schuck, R.N.; Oni-Orisan, A.; Miller, T.M.; Kannon, M.A.; Poloyac, S.M.; Lee, C.R. Enalapril reverses high-fat diet-induced alterations in cytochrome P450-mediated eicosanoid metabolism. Am. J. Physiol. Endocrinol. Metab. 2012, 302, E500-E509. [CrossRef] [PubMed]

182. Abdelmegeed, M.A.; Banerjee, A.; Yoo, S.H.; Jang, S.; Gonzalez, F.J.; Song, B.J. Critical role of cytochrome P450 2E1 (CYP2E1) in the development of high fat-induced non-alcoholic steatohepatitis. J. Hepatol. 2012, 57, 860-866. [CrossRef] [PubMed]

183. Rankinen, T.; Zuberi, A.; Chagnon, Y.C.; Weisnagel, S.J.; Argyropoulos, G.; Walts, B.; Perusse, L.; Bouchard, C. The human obesity gene map: The 2005 update. Obesity (Silver Spring) 2006, 14, 529-644. [CrossRef] [PubMed]

184. Zelber-Sagi, S.; Azar, S.; Nemirovski, A.; Webb, M.; Halpern, Z.; Shibolet, O.; Tam, J. Serum levels of endocannabinoids are independently associated with nonalcoholic fatty liver disease. Obesity (Silver Spring) 2017, 25, 94-101. [CrossRef] [PubMed]

185. Gonzalez-Periz, A.; Horrillo, R.; Ferre, N.; Gronert, K.; Dong, B.; Moran-Salvador, E.; Titos, E.; Martinez-Clemente, M.; Lopez-Parra, M.; Arroyo, V.; et al. Obesity-induced insulin resistance and hepatic steatosis are alleviated by omega-3 fatty acids: A role for resolvins and protectins. FASEB J. 2009, 23, 1946-1957. [CrossRef] [PubMed]

186. Lopez-Vicario, C.; Gonzalez-Periz, A.; Rius, B.; Moran-Salvador, E.; Garcia-Alonso, V.; Lozano, J.J.; Bataller, R.; Cofan, M.; Kang, J.X.; Arroyo, V.; et al. Molecular interplay between Delta5/Delta6 desaturases and long-chain fatty acids in the pathogenesis of non-alcoholic steatohepatitis. Gut 2014, 63, 344-355. [CrossRef] [PubMed]

187. Dongiovanni, P.; Fracanzani, A.L.; Fargion, S.; Valenti, L. Iron in fatty liver and in the metabolic syndrome: A promising therapeutic target. J. Hepatol. 2011, 55, 920-932. [CrossRef] [PubMed]

188. Aigner, E.; Theurl, I.; Theurl, M.; Lederer, D.; Haufe, H.; Dietze, O.; Strasser, M.; Datz, C.; Weiss, G. Pathways underlying iron accumulation in human nonalcoholic fatty liver disease. Am. J. Clin. Nutr. 2008, 87, 1374-1383. [CrossRef] [PubMed]

189. Steinberg, D. Thematic review series: The pathogenesis of atherosclerosis. An interpretive history of the cholesterol controversy: Part II: The early evidence linking hypercholesterolemia to coronary disease in humans. J. Lipid Res. 2005, 46, 179-190. [CrossRef] [PubMed]

190. Steinberg, D. Thematic review series: The pathogenesis of atherosclerosis. An interpretive history of the cholesterol controversy: Part I. J. Lipid Res. 2004, 45, 1583-1593. [CrossRef] [PubMed]

191. Kawakami, A.; Osaka, M.; Aikawa, M.; Uematsu, S.; Akira, S.; Libby, P.; Shimokado, K.; Sacks, F.M.; Yoshida, M. Toll-like receptor 2 mediates apolipoprotein CIII-induced monocyte activation. Circ. Res. 2008, 103, 1402-1409. [CrossRef] [PubMed]

192. Witztum, J.L.; Steinberg, D. Role of oxidized low density lipoprotein in atherogenesis. J. Clin. Investig. 1991, 88, 1785-1792. [CrossRef] [PubMed] 
193. Swirski, F.K.; Libby, P.; Aikawa, E.; Alcaide, P.; Luscinskas, F.W.; Weissleder, R.; Pittet, M.J. Ly-6Chi monocytes dominate hypercholesterolemia-associated monocytosis and give rise to macrophages in atheromata. J. Clin. Investig. 2007, 117, 195-205. [CrossRef] [PubMed]

194. Engler, R.L.; Schmid-Schonbein, G.W.; Pavelec, R.S. Leukocyte capillary plugging in myocardial ischemia and reperfusion in the dog. Am. J. Pathol. 1983, 111, 98-111. [PubMed]

195. Jolly, S.R.; Kane, W.J.; Hook, B.G.; Abrams, G.D.; Kunkel, S.L.; Lucchesi, B.R. Reduction of myocardial infarct size by neutrophil depletion: Effect of duration of occlusion. Am. Heart J. 1986, 112, 682-690. [CrossRef]

196. Swirski, F.K.; Nahrendorf, M. Leukocyte behavior in atherosclerosis, myocardial infarction, and heart failure. Science 2013, 339, 161-166. [CrossRef] [PubMed]

197. Tacke, F.; Alvarez, D.; Kaplan, T.J.; Jakubzick, C.; Spanbroek, R.; Llodra, J.; Garin, A.; Liu, J.; Mack, M.; van Rooijen, N.; et al. Monocyte subsets differentially employ CCR2, CCR5, and CX3CR1 to accumulate within atherosclerotic plaques. J. Clin. Investig. 2007, 117, 185-194. [CrossRef] [PubMed]

198. Yamamoto, H.; Yoshida, N.; Shinke, T.; Otake, H.; Kuroda, M.; Sakaguchi, K.; Hirota, Y.; Toba, T.; Takahashi, H.; Terashita, D.; et al. Impact of CD14(++)CD16(+) monocytes on coronary plaque vulnerability assessed by optical coherence tomography in coronary artery disease patients. Atherosclerosis 2018, 269, 245-251. [CrossRef] [PubMed]

199. Rogacev, K.S.; Cremers, B.; Zawada, A.M.; Seiler, S.; Binder, N.; Ege, P.; Grosse-Dunker, G.; Heisel, I.; Hornof, F.; Jeken, J.; et al. CD14++CD16+ monocytes independently predict cardiovascular events: A cohort study of 951 patients referred for elective coronary angiography. J. Am. Coll. Cardiol. 2012, 60, 1512-1520. [CrossRef] [PubMed]

200. Demetz, E.; Schroll, A.; Auer, K.; Heim, C.; Patsch, J.R.; Eller, P.; Theurl, M.; Theurl, I.; Theurl, M.; Seifert, M.; et al. The arachidonic acid metabolome serves as a conserved regulator of cholesterol metabolism. Cell Metab. 2014, 20, 787-798. [CrossRef] [PubMed]

201. Zhou, G.; Ge, S.; Liu, D.; Xu, G.; Zhang, R.; Yin, Q.; Zhu, W.; Chen, J.; Liu, X. Atorvastatin reduces plaque vulnerability in an atherosclerotic rabbit model by altering the 5-lipoxygenase pathway. Cardiology 2010, 115, 221-228. [CrossRef] [PubMed]

202. Weber, C.; Zernecke, A.; Libby, P. The multifaceted contributions of leukocyte subsets to atherosclerosis: Lessons from mouse models. Nat. Rev. Immunol. 2008, 8, 802-815. [CrossRef] [PubMed]

203. Zernecke, A.; Bot, I.; Djalali-Talab, Y.; Shagdarsuren, E.; Bidzhekov, K.; Meiler, S.; Krohn, R.; Schober, A.; Sperandio, M.; Soehnlein, O.; et al. Protective role of CXC receptor 4/CXC ligand 12 unveils the importance of neutrophils in atherosclerosis. Circ. Res. 2008, 102, 209-217. [CrossRef] [PubMed]

204. Nagareddy, P.R.; Murphy, A.J.; Stirzaker, R.A.; Hu, Y.; Yu, S.; Miller, R.G.; Ramkhelawon, B.; Distel, E.; Westerterp, M.; Huang, L.S.; et al. Hyperglycemia promotes myelopoiesis and impairs the resolution of atherosclerosis. Cell Metab. 2013, 17, 695-708. [CrossRef] [PubMed]

205. Levy, B.D.; Clish, C.B.; Schmidt, B.; Gronert, K.; Serhan, C.N. Lipid mediator class switching during acute inflammation: Signals in resolution. Nat. Immunol. 2001, 2, 612-619. [CrossRef] [PubMed]

206. Miyahara, T.; Runge, S.; Chatterjee, A.; Chen, M.; Mottola, G.; Fitzgerald, J.M.; Serhan, C.N.; Conte, M.S. D-series resolvin attenuates vascular smooth muscle cell activation and neointimal hyperplasia following vascular injury. FASEB J. 2013, 27, 2220-2232. [CrossRef] [PubMed]

207. Ho, K.J.; Spite, M.; Owens, C.D.; Lancero, H.; Kroemer, A.H.; Pande, R.; Creager, M.A.; Serhan, C.N.; Conte, M.S. Aspirin-triggered lipoxin and resolvin E1 modulate vascular smooth muscle phenotype and correlate with peripheral atherosclerosis. Am. J. Pathol. 2010, 177, 2116-2123. [CrossRef] [PubMed]

208. Hachicha, M.; Pouliot, M.; Petasis, N.A.; Serhan, C.N. Lipoxin (LX)A4 and aspirin-triggered 15-epi-LXA4 inhibit tumor necrosis factor 1alpha-initiated neutrophil responses and trafficking: Regulators of a cytokine-chemokine axis. J. Exp. Med. 1999, 189, 1923-1930. [CrossRef] [PubMed]

209. Sodin-Semrl, S.; Taddeo, B.; Tseng, D.; Varga, J.; Fiore, S. Lipoxin A4 inhibits IL-1 beta-induced IL-6, IL-8, and matrix metalloproteinase-3 production in human synovial fibroblasts and enhances synthesis of tissue inhibitors of metalloproteinases. J. Immunol. 2000, 164, 2660-2666. [CrossRef] [PubMed]

210. Petri, M.H.; Laguna-Fernandez, A.; Arnardottir, H.; Wheelock, C.E.; Perretti, M.; Hansson, G.K.; Back, M. Aspirin-triggered lipoxin A4 inhibits atherosclerosis progression in apolipoprotein $\mathrm{E}(-/-)$ mice. Br. J. Pharmacol. 2017, 174, 4043-4054. [CrossRef] [PubMed] 
211. Zhao, L.; Moos, M.P.; Grabner, R.; Pedrono, F.; Fan, J.; Kaiser, B.; John, N.; Schmidt, S.; Spanbroek, R.; Lotzer, K.; et al. The 5-lipoxygenase pathway promotes pathogenesis of hyperlipidemia-dependent aortic aneurysm. Nat. Med. 2004, 10, 966-973. [CrossRef] [PubMed]

212. Brink, C.; Dahlen, S.E.; Drazen, J.; Evans, J.F.; Hay, D.W.; Nicosia, S.; Serhan, C.N.; Shimizu, T.; Yokomizo, T. International Union of Pharmacology XXXVII. Nomenclature for leukotriene and lipoxin receptors. Pharmacol. Rev. 2003, 55, 195-227. [CrossRef] [PubMed]

213. Maekawa, A.; Kanaoka, Y.; Xing, W.; Austen, K.F. Functional recognition of a distinct receptor preferential for leukotriene E4 in mice lacking the cysteinyl leukotriene 1 and 2 receptors. Proc. Natl. Acad. Sci. USA 2008, 105, 16695-16700. [CrossRef] [PubMed]

214. Paruchuri, S.; Jiang, Y.; Feng, C.; Francis, S.A.; Plutzky, J.; Boyce, J.A. Leukotriene E4 activates peroxisome proliferator-activated receptor gamma and induces prostaglandin D2 generation by human mast cells. J. Biol. Chem. 2008, 283, 16477-16487. [CrossRef] [PubMed]

215. Paruchuri, S.; Tashimo, H.; Feng, C.; Maekawa, A.; Xing, W.; Jiang, Y.; Kanaoka, Y.; Conley, P.; Boyce, J.A. Leukotriene E4-induced pulmonary inflammation is mediated by the P2Y12 receptor. J. Exp. Med. 2009, 206, 2543-2555. [CrossRef] [PubMed]

216. Feuerstein, G. Leukotrienes and the cardiovascular system. Prostaglandins 1984, 27, 781-802. [CrossRef]

217. Folco, G.; Rossoni, G.; Buccellati, C.; Berti, F.; Maclouf, J.; Sala, A. Leukotrienes in cardiovascular diseases. Am. J. Respir. Crit. Care Med. 2000, 161, 1121. [CrossRef] [PubMed]

218. Walch, L.; Norel, X.; Gascard, J.P.; Brink, C. Functional studies of leukotriene receptors in vascular tissues. Am. J. Respir. Crit. Care Med. 2000, 161, 1071. [CrossRef] [PubMed]

219. McIntyre, T.M.; Zimmerman, G.A.; Prescott, S.M. Leukotrienes C4 and D4 stimulate human endothelial cells to synthesize platelet-activating factor and bind neutrophils. Proc. Natl. Acad. Sci. USA 1986, 83, 2204-2208. [CrossRef] [PubMed]

220. Datta, Y.H.; Romano, M.; Jacobson, B.C.; Golan, D.E.; Serhan, C.N.; Ewenstein, B.M. Peptido-leukotrienes are potent agonists of von Willebrand factor secretion and P-selectin surface expression in human umbilical vein endothelial cells. Circulation 1995, 92, 3304-3311. [CrossRef] [PubMed]

221. De Caterina, R.; Mazzone, A.; Giannessi, D.; Sicari, R.; Pelosi, W.; Lazzerini, G.; Azzara, A.; Forder, R.; Carey, F.; Caruso, D.; et al. Leukotriene B4 production in human atherosclerotic plaques. Biomed. Biochim. Acta 1988, 47, 1821.

222. Spanbroek, R.; Grabner, R.; Lotzer, K.; Hildner, M.; Urbach, A.; Ruhling, K.; Moos, M.P.; Kaiser, B.; Cohnert, T.U.; Wahlers, T.; et al. Expanding expression of the 5-lipoxygenase pathway within the arterial wall during human atherogenesis. Proc. Natl. Acad. Sci. USA 2003, 100, 1238-1243. [CrossRef] [PubMed]

223. Cipollone, F.; Mezzetti, A.; Fazia, M.L.; Cuccurullo, C.; Iezzi, A.; Ucchino, S.; Spigonardo, F.; Bucci, M.; Cuccurullo, F.; Prescott, S.M.; et al. Association between 5-lipoxygenase expression and plaque instability in humans. Arter. Thromb. Vasc. Biol. 2005, 25, 1665-1670. [CrossRef] [PubMed]

224. Ketelhuth, D.F.; Hermansson, A.; Hlawaty, H.; Letourneur, D.; Yan, Z.Q.; Back, M. The leukotriene B4 receptor (BLT) antagonist BIIL284 decreases atherosclerosis in $\mathrm{ApoE}^{-/-}$mice. Prostaglandins Other Lipid Mediat. 2015, 121, 105-109. [CrossRef] [PubMed]

225. Jiang, W.; Hall, S.R.; Moos, M.P.; Cao, R.Y.; Ishii, S.; Ogunyankin, K.O.; Melo, L.G.; Funk, C.D. Endothelial cysteinyl leukotriene 2 receptor expression mediates myocardial ischemia-reperfusion injury. Am. J. Pathol. 2008, 172, 592-602. [CrossRef] [PubMed]

226. Hui, Y.; Cheng, Y.; Smalera, I.; Jian, W.; Goldhahn, L.; Fitzgerald, G.A.; Funk, C.D. Directed vascular expression of human cysteinyl leukotriene 2 receptor modulates endothelial permeability and systemic blood pressure. Circulation 2004, 110, 3360-3366. [CrossRef] [PubMed]

227. Qiu, H.; Gabrielsen, A.; Agardh, H.E.; Wan, M.; Wetterholm, A.; Wong, C.H.; Hedin, U.; Swedenborg, J.; Hansson, G.K.; Samuelsson, B.; et al. Expression of 5-lipoxygenase and leukotriene A4 hydrolase in human atherosclerotic lesions correlates with symptoms of plaque instability. Proc. Natl. Acad. Sci. USA 2006, 103, 8161-8166. [CrossRef] [PubMed]

228. Helgadottir, A.; Manolescu, A.; Thorleifsson, G.; Gretarsdottir, S.; Jonsdottir, H.; Thorsteinsdottir, U.; Samani, N.J.; Gudmundsson, G.; Grant, S.F.; Thorgeirsson, G.; et al. The gene encoding 5-lipoxygenase activating protein confers risk of myocardial infarction and stroke. Nat. Genet. 2004, 36, 233-239. [CrossRef] [PubMed] 
229. Helgadottir, A.; Manolescu, A.; Helgason, A.; Thorleifsson, G.; Thorsteinsdottir, U.; Gudbjartsson, D.F.; Gretarsdottir, S.; Magnusson, K.P.; Gudmundsson, G.; Hicks, A.; et al. A variant of the gene encoding leukotriene A4 hydrolase confers ethnicity-specific risk of myocardial infarction. Nat. Genet. 2006, 38, 68-74. [CrossRef] [PubMed]

230. Mehrabian, M.; Allayee, H.; Wong, J.; Shi, W.; Wang, X.P.; Shaposhnik, Z.; Funk, C.D.; Lusis, A.J. Identification of 5-lipoxygenase as a major gene contributing to atherosclerosis susceptibility in mice. Circ. Res. 2002, 91, 120-126. [CrossRef] [PubMed]

231. Jawien, J.; Gajda, M.; Rudling, M.; Mateuszuk, L.; Olszanecki, R.; Guzik, T.J.; Cichocki, T.; Chlopicki, S.; Korbut, R. Inhibition of five lipoxygenase activating protein (FLAP) by MK-886 decreases atherosclerosis in apoE/LDLR-double knockout mice. Eur. J. Clin. Investig. 2006, 36, 141-146. [CrossRef] [PubMed]

232. Jawien, J.; Gajda, M.; Olszanecki, R.; Korbut, R. BAY x 1005 attenuates atherosclerosis in apoE/LDLR—Double knockout mice. J. Physiol. Pharmacol. 2007, 58, 583-588. [PubMed]

233. Mawhin, M.A.; Tilly, P.; Zirka, G.; Charles, A.L.; Slimani, F.; Vonesch, J.L.; Michel, J.B.; Back, M.; Norel, X.; Fabre, J.E. Neutrophils recruited by leukotriene B4 induce features of plaque destabilization during endotoxemia. Cardiovasc. Res. 2018. [CrossRef] [PubMed]

234. Moos, M.P.; Funk, C.D. Endothelial cysteinyl leukotriene 2 receptor expression and myocardial ischemia/reperfusion injury. Trends Cardiovasc. Med. 2008, 18, 268-273. [CrossRef] [PubMed]

235. De Hoog, V.C.; Bovens, S.M.; de Jager, S.C.; van Middelaar, B.J.; van Duijvenvoorde, A.; Doevendans, P.A.; Pasterkamp, G.; de Kleijn, D.P.; Timmers, L. BLT1 antagonist LSN2792613 reduces infarct size in a mouse model of myocardial ischaemia-reperfusion injury. Cardiovasc. Res. 2015, 108, 367-376. [CrossRef] [PubMed]

236. Becher, U.M.; Ghanem, A.; Tiyerili, V.; Furst, D.O.; Nickenig, G.; Mueller, C.F. Inhibition of leukotriene C4 action reduces oxidative stress and apoptosis in cardiomyocytes and impedes remodeling after myocardial injury. J. Mol. Cell. Cardiol. 2011, 50, 570-577. [CrossRef] [PubMed]

237. Nobili, E.; Salvado, M.D.; Folkersen, L.; Castiglioni, L.; Kastrup, J.; Wetterholm, A.; Tremoli, E.; Hansson, G.K.; Sironi, L.; Haeggstrom, J.Z.; et al. Cysteinyl leukotriene signaling aggravates myocardial hypoxia in experimental atherosclerotic heart disease. PLoS ONE 2012, 7, e41786. [CrossRef] [PubMed]

238. Allayee, H.; Hartiala, J.; Lee, W.; Mehrabian, M.; Irvin, C.G.; Conti, D.V.; Lima, J.J. The effect of montelukast and low-dose theophylline on cardiovascular disease risk factors in asthmatics. Chest 2007, 132, 868-874. [CrossRef] [PubMed]

239. Ingelsson, E.; Yin, L.; Back, M. Nationwide cohort study of the leukotriene receptor antagonist montelukast and incident or recurrent cardiovascular disease. J. Allergy Clin. Immunol. 2012, 129, 702-707. [CrossRef] [PubMed]

240. Hoxha, M.; Rovati, G.E.; Cavanillas, A.B. The leukotriene receptor antagonist montelukast and its possible role in the cardiovascular field. Eur. J. Clin. Pharmacol. 2017, 73, 799-809. [CrossRef] [PubMed]

241. Vane, J.R. Inhibition of prostaglandin synthesis as a mechanism of action for aspirin-like drugs. Nat. New. Biol. 1971, 231, 232-235. [CrossRef] [PubMed]

242. Leal, M.A.S.; Dias, A.T.; Porto, M.L.; Brun, B.F.; Gava, A.L.; Meyrelles, S.S.; Gil-Longo, J.; Campos-Toimil, M.; Pereira, T.M.C.; Vasquez, E.C. Sildenafil (Viagra ${ }^{\circledR}$ ) Prevents Cox-1/ TXA2 Pathway-Mediated Vascular Hypercontractility in ApoE ${ }^{-/-}$Mice. Cell. Physiol. Biochem. 2017, 44, 1796-1809. [CrossRef] [PubMed]

243. Rothwell, P.M.; Cook, N.R.; Gaziano, J.M.; Price, J.F.; Belch, J.F.F.; Roncaglioni, M.C.; Morimoto, T.; Mehta, Z. Effects of aspirin on risks of vascular events and cancer according to bodyweight and dose: Analysis of individual patient data from randomised trials. Lancet 2018, 392, 387-399. [CrossRef]

244. MacDonald, T.M.; Hawkey, C.J.; Ford, I.; McMurray, J.J.V.; Scheiman, J.M.; Hallas, J.; Findlay, E.; Grobbee, D.E.; Hobbs, F.D.R.; Ralston, S.H.; et al. Randomized trial of switching from prescribed non-selective non-steroidal anti-inflammatory drugs to prescribed celecoxib: The Standard care vs. Celecoxib Outcome Trial (SCOT). Eur. Heart J. 2017, 38, 1843-1850. [CrossRef] [PubMed]

245. Nissen, S.E.; Yeomans, N.D.; Solomon, D.H.; Luscher, T.F.; Libby, P.; Husni, M.E.; Graham, D.Y.; Borer, J.S.; Wisniewski, L.M.; Wolski, K.E.; et al. Cardiovascular Safety of Celecoxib, Naproxen, or Ibuprofen for Arthritis. N. Engl. J. Med. 2016, 375, 2519-2529. [CrossRef] [PubMed]

246. Celotti, F.; Durand, T. The metabolic effects of inhibitors of 5-lipoxygenase and of cyclooxygenase 1 and 2 are an advancement in the efficacy and safety of anti-inflammatory therapy. Prostaglandins Other Lipid Mediat. 2003, 71, 147-162. [CrossRef]

247. Imig, J.D. Epoxide hydrolase and epoxygenase metabolites as therapeutic targets for renal diseases. Am. J. Physiol. Renal. Physiol. 2005, 289, F496-F503. [CrossRef] [PubMed] 
248. Neckar, J.; Kopkan, L.; Huskova, Z.; Kolar, F.; Papousek, F.; Kramer, H.J.; Hwang, S.H.; Hammock, B.D.; Imig, J.D.; Maly, J.; et al. Inhibition of soluble epoxide hydrolase by cis-4-[4-(3-adamantan-1ylureido)cyclohexyl-oxy]benzoic acid exhibits antihypertensive and cardioprotective actions in transgenic rats with angiotensin II-dependent hypertension. Clin. Sci. (Lond.) 2012, 122, 513-525. [CrossRef] [PubMed]

249. Duflot, T.; Roche, C.; Lamoureux, F.; Guerrot, D.; Bellien, J. Design and discovery of soluble epoxide hydrolase inhibitors for the treatment of cardiovascular diseases. Expert Opin. Drug Discov. 2014, 9, $229-243$. [CrossRef] [PubMed]

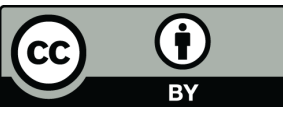

(C) 2018 by the authors. Licensee MDPI, Basel, Switzerland. This article is an open access article distributed under the terms and conditions of the Creative Commons Attribution (CC BY) license (http://creativecommons.org/licenses/by/4.0/). 